\title{
Accelerated Degradation of High-Temperature Polymer Electrolyte Fuel Cells: Discussion and Empirical Modeling
}

\author{
Uwe Reimer, ${ }^{\mathrm{a}, \mathrm{z}}$ Birgit Schumacher, ${ }^{\mathrm{a}}$ and Werner Lehnert ${ }^{\mathrm{a}, \mathrm{b}, *}$ \\ ${ }^{a}$ Forschungszentrum Jülich GmbH, Institute of Energy and Climate Research, Electrochemical Process Engineering, \\ 52425 Jülich, Germany \\ ${ }^{b}$ Modeling in Electrochemical Process Engineering, RWTH Aachen University, Aachen, Germany
}

\begin{abstract}
Accelerated stress tests are commonly applied in order to obtain a prediction of fuel cell life time within a short testing period. The stress test in this work considers a fuel cell which is constantly under load with frequent periods of very high current. Four different cells were operated each with a specific load profile. As a result severe performance degradation was observed in the region of high current densities. A short overview over the phenomena which may contribute to this specific fuel cell degradation is compiled from literature. Based on this overview major degradation modes are identified and combined with a simple polarization curve model. The modeling results allow for two different interpretations. Carbon corrosion reactions can explain the observed effects if cell voltage is assumed as the driving force for degradation. A better fit was obtained by using the overall heat flux as degradation criterion. In this case an increase in local temperature could lead to redistribution and loss of phosphoric acid from the MEA. The results are supported by the fact that the model yields consistent time dependend results for four different and non-periodic load cycles.

(c) The Author(s) 2014. Published by ECS. This is an open access article distributed under the terms of the Creative Commons Attribution 4.0 License (CC BY, http://creativecommons.org/licenses/by/4.0/), which permits unrestricted reuse of the work in any medium, provided the original work is properly cited. [DOI: 10.1149/2.0961501jes] All rights reserved.
\end{abstract}

Manuscript submitted October 17, 2014; revised manuscript received November 17, 2014. Published December 1, 2014.

The expected lifetime of a polymer electrolyte fuel cell (PEFC) ranges from $5000 \mathrm{~h}$ for mobile application to $40000 \mathrm{~h}$ for stationary application..$^{1,2}$ In order to gain information about time dependent degradation in advance accelerated test protocols are used. ${ }^{3,4}$ Depending on the design of these tests valuable information about the nature of the main degradation mode under the applied operation conditions can be obtained. Despite the difference in operation conditions for PEFC, HT-PEFC and PAFC the structure and material of the electrodes are almost the same. Consequently, observed degradation phenomena show strong similarities. ${ }^{5}$ A good description of these phenomena can be found in several review papers ${ }^{6-13}$ as well as in at least four books ${ }^{1,2,14,15}$ where recent experimental facts and interpretations are summarized. A compact description can also be found in a recent review paper on modeling transport phenomena in PEFCs. ${ }^{16}$

The purpose of this paper is to present the results of a specific accelerated degradation test for high temperature polymer electrolyte fuel cells (HT-PEFC) with phosphoric acid doped polybenzimidazole $\left(\mathrm{PBI} / \mathrm{H}_{3} \mathrm{PO}_{4}\right)$ membranes. The fuel cell is constantly under load with frequent periods of very high current. In order to accelerate degradation effects the fuel cell is operated beyond it's point of maximum power. A simple polarization curve model is used as starting point for the analysis of data. Based on this first analysis a degradation model is proposed which allows for a straightforward physical interpretation. The complexity of degradation effects which occur simultaneousy usually leads to models which either resolve a specific mechanism in depth or describe more general effects. This paper aims at general effects which requires a broader understanding of degradation. In the following it is attempted to provide an overview over the phenomena which may contribute to fuel cell degradation. Based on this overview major degradation modes are identified and used later in the modeling part.

\section{Catalyst Layer and Carbon Support Degradation}

Catalyst degradation. - Catalyst degradation is the result of a complex interplay of platinum dissolution, agglomeration, platinum particle detachment and carbon corrosion..$^{6,11,12,17-20}$ As a result inhomogeneous degradation behavior for different catalyst locations can be observed by identical location transmission electron microscopy, ${ }^{21}$ which arise from the fact that fuel cell electrode layers are composite materials with inherent inhomogeneities at the level of catalyst

\footnotetext{
${ }^{*}$ Electrochemical Society Active Member.
}

${ }^{\mathrm{z}}$ E-mail: u.reimer@fz-juelich.de particles. The platinum catalyst itself seems to be dissolved slowly at cell voltages from $0.65 \mathrm{~V}$ to $1.1 \mathrm{~V} .^{11,22}$ Besides cell potential also humidity and temperature affect platinum degradation. ${ }^{6}$ Interestingly, the effects of platinum particle dissolution and coarsening (so called Ostwald ripening) seem to contribute equally to the overall loss of electrochemically active surface area (ECSA) of PEFCs. ${ }^{23}$ The overall concentration of dissolved platinum ions is very small ${ }^{11}$ which is in accordance with the fact that the dissolution is an endergonic process (it requires energy).

For PAFC similar behavior of catalyst degradation is described as for PEFC. Severe corrosion takes place at the cathode at high potential and high oxygen partial pressure. ${ }^{24,25}$ Platinum dissolution/ agglomeration is enhanced by the presence of air and phosphoric acid and takes place at potentials above $0.8 \mathrm{~V}^{26,27}$ Platinum dissolution is assumed to be the main degradation process at $1.0 \mathrm{~V}^{27}$ The dissolution rate of platinum is a function of temperature and fuel cell potential. ${ }^{28}$ For HT-PEFC it was reported that at cell voltages above $0.9 \mathrm{~V}$ cathode degradation is severe wheras the anode seems to be not affected. ${ }^{9}$

Carbon corrosion.- In parallel to the degradation of platinum particles also corrosion of the carbon support is observed, which leads to loss of contact with the platinum catalyst and therefore to a decrease of the ECSA. The thickness of the cathode catalyst layer decreases ${ }^{11,29}$ and carbon dioxide is released. ${ }^{30-35}$ The collapsed structure of the catalyst layer can also lead to an increase in mass transport losses which was assessed by impedance spectroscopy. ${ }^{29}$ This was confirmed with 3D imaging techniques which show that the pore structure of the support changes from an interconnected network to a dense layer. ${ }^{36}$ A different morphological change was observed by in-situ soft X-ray tomography where carbon corrosion led to the formation of cracks in the cathode catalyst layer at the outlet region after 300 cycles of start up and shut down. ${ }^{37}$ The amount of ECSA lost seems to depend on the specific surface area of the specific carbon support and the number of defect sites, which was shown in half cell experiments with accelerated stress tests. ${ }^{38}$ This process takes places especially at load cycling close to OCV values and seems to be catalyzed by platinum. $^{38}$

The formation of carbon dioxide as product of carbon corrosion is usually observed at potentials larger than $1.0 \mathrm{~V} .^{30,33,34}$ The small release of carbon dioxide at potentials $\approx 0.5 \mathrm{~V}$ could be explained by selective oxidation of carbon monoxide adsorbed at the catalyst. ${ }^{30}$ Commonly the reaction of water with carbon (Eq. 1) is quoted as the source for carbon corrosion ${ }^{6-13}$ (all relating back to ${ }^{39}$ ) although the 
potential is too low for OCV conditions.

$$
\mathrm{C}+2 \mathrm{H}_{2} \mathrm{O} \rightarrow \mathrm{CO}_{2}+2 \mathrm{H}_{2} \quad E^{\circ}=0.21 \mathrm{~V}
$$

The reaction of carbon with oxygen is less frequently considered, although it is known that the presence of oxygen increases the rate of carbon corrosion drastically ${ }^{20,31,40,41}$ and several pathways for the reaction are discussed. ${ }^{40}$ Furthermore, carbon corrosion seems to depend upon the presence of catalyst. ${ }^{30,42,43}$ On the other hand carbon corrosion is also observed in the absence of oxygen..$^{20,40,44}$ At a constant potential of $1.4 \mathrm{~V}$ no difference could be detected in carbon corrosion as humidified oxygen or humidified nitrogen was applied. ${ }^{45}$ Additionally, the effect of cycling enhances corrosion in general. ${ }^{8,23,44,46}$

The carbon corrosion in PAFC is described in a similar way by oxidation of surface groups. ${ }^{47}$ It is observed that the initial rate of carbon corrosion decreases fast with operation time, in one case the carbon support lost $7 \%$ of its weight within the first 16 hours. ${ }^{47}$ Carbon corrosion and platinum dissolution/ agglomeration lead to morphological changes in the catalyst layer. ${ }^{48-50}$ Additionally, increased degradation of Teflon at the cathode was reported. ${ }^{51}$

For HT-PEFC the formation of carbon dioxide as product of carbon corrosion is observed at potentials larger than $1.0 \mathrm{~V}^{34}$ The operation at $\mathrm{OCV}$ condition and $180^{\circ} \mathrm{C}$ leads to an increase of platinum particle size at the cathode while anode catalyst shows very little change. ${ }^{52}$ A similar result was obtained while operating the fuel cell under constant load at $\approx 0.55 \mathrm{~V}$ and $150^{\circ} \mathrm{C}$. The main effect is loss of ECSA whereas there is little change in membrane resistance. ${ }^{53,54}$ An increase in voltage to $\approx 0.65 \mathrm{~V}$ in a similar experiment lead to additional effects: membrane thinning, loss of phosphoric acid and increase in platinum particle size both for cathode and anode. ${ }^{55}$ A comparable study under constant load condition at $\approx 0.65 \mathrm{~V}$ and $160^{\circ} \mathrm{C}$ confirmed platinum particle coarsening as the main degradation mechanism. ${ }^{56}$ For long term operation over $6000 \mathrm{~h}\left(160^{\circ} \mathrm{C}\right)$ it was observed that start/ stop cycling dramatically increases degradation compared to constant load condition. ${ }^{57}$ Loss of ECSA at the cathode was derived as the main cause from analysis of the polarization curves. Similar results were obtained in another long term test for $17000 \mathrm{~h}$ at constant current density of $0.2 \mathrm{~W} \mathrm{~cm}^{-2}$ (and cell voltage $\geq 0.6 \mathrm{~V}$ ) where carbon corrosion and catalyst particle coarsening were identified as main degradation effects. ${ }^{58}$

In summary it can be reasoned that the oxidation of carbon takes place through several pathways. Oxygen may either be provided as gas, through the reaction with water or through surface groups. Potential cycling could lead to a successive oxidation/ reduction of surface groups present at the carbon support and other defect sites. At these sites carbon corrosion and platinum particle degradation take place simultaneously ${ }^{33,35,59}$ whereas the ionomer from the polymer electrolyte seems to remain stable. ${ }^{59}$

Fuel starvation conditions. - Fuel starvation conditions occur at very high fuel utilization, start/ stop conditions and purging the anode with air. The underlying mechanism seem to be different for 'mild' (local) starvation and 'severe' (overall) starvation. ${ }^{11}$ In case of overall fuel starvation, the cell voltage reaches negative values the cause being an increase of the anode potential to values larger than $1.0 \mathrm{~V}$ while the cathode potential remains at 'normal' working potential smaller than $1.0 \mathrm{~V} .{ }^{60}$ Under these conditions severe catalyst corrosion was observed at the anode and to a lesser extend at the cathode ${ }^{60}$ and carbon dioxide ${ }^{61}$ and oxygen ${ }^{62}$ are observed in the anode off gas. The sources are carbon corrosion from reaction with water and possibly water electrolysis at very high anode potentials. In the cathode off gas hydrogen can be detected ${ }^{61}$ and also the local cathode potential was shown to increase. Similar phenomena are also described for PAFC. In experiments with several local reference electrodes it was observed that degradation at the anode occurs at high hydrogen utilization and at (locally) negative voltages. ${ }^{24,25}$

Local starvation can be caused either by reactants maldistribution within the flowfield, anode dead end operation or by temporal insertion of a second gas at the anode. The latter effect can occur during startup or purging. In case of local starvation carbon dioxide can be detected in the cathode off gas if the cell is in dead end operation or being purged. ${ }^{61}$ Another experiment with repeated purging in simulated start/ stop cycling showed that cathode catalyst layer thickness was reduced to about $1 / 3$ of its initial value wheras the anode catalyst seemed not changed. ${ }^{63}$ It has to mentioned that the anode catalyst layer was more than twice as thick as the cathode, therefore changes in anode catalyst layer may have been difficult to detect. A concept for local starvation was introduced, ${ }^{64}$ where the term 'reverse current mechanism' origins from the fact that within the starvation area protons are transported from cathode to anode. The source for protons at the cathode are water electrolysis and carbon corrosion. At the anode water is assumed to be produced by oxygen which origins from the cathode by means of diffusion. The total degradation effect seems to depend strongly on local conditions. Some groups found degradation to be more severe during the shut down process ${ }^{32,65}$ whereas another group ${ }^{66}$ reports higher degradation for the start up process. This may be because degradation depends on the residence time of the gas front which passes through the cell and thus on the specific test protocol for start up and shut down. ${ }^{65}$ A detailed discussion of degradation phenomena in start/stop procedures can be found here. ${ }^{13}$

\section{Degradation of Polymer Membranes}

The three main degradation mechanisms for fuel cell membranes are chemical degradation, mechanical degradation and thermal

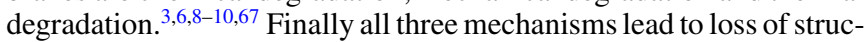
tural integrity by cleaving chemical bonds of the polymer network. The polymer network in combination with the electrolyte (water or phosphoric acid) facilitates proton conductivity. Therefore, the overall resistance increases or the cell performance breaks down as pinholes are formed.

Chemical degradation is described as oxidative stress caused by hydrogen peroxide, which occurs at the catalyst in small amounts as side product. The formation of hydrogen peroxide in the oxygen reduction reaction on $\mathrm{Pt} / \mathrm{C}$ catalysts was characterized by rotating ring disk electrode experiments. ${ }^{68,69}$ The interaction of hydrogen peroxide with the membrane is frequently used in order to probe the long term stability of PEFC membranes. ${ }^{70-73}$ The presence of radicals formed from hydrogen peroxide was mainly detected at the cathode of PEFCs and is promoted by small impurities like iron ions. ${ }^{74-76}$ In real fuel cell applications the membrane also interacts with other components. For Nafion type membranes a controversal dependence of degradation on the total current density was observed, ${ }^{77}$ which depends on the presence of micro porous layers.

Mechanical stress occurs especially under load cycling, where PEFC membranes swell and shrink. ${ }^{78}$ This degradation mode can be reduced by increasing the mechanical strength of the membrane. One option for PBI type membranes is thermal treatment which increases cross-linking and leads to higher cycle stability. ${ }^{79}$ Another approach is to modify the chemical structure of the PBI polymer. ${ }^{80}$

\section{Electrolyte Degradation in HT-PEFC and PAFC}

The loss of phosphoric acid from the MEA is ususally small and depends on operation conditions. An increased acid loss can be observed for temperatures $\geq 180^{\circ} \mathrm{C}$ and high electric load. ${ }^{81}$ Therefore, it was assumed that the phosphoric acid is dragged by water steam (steam distillation mechanism) ${ }^{81}$ On the other hand long term investigations of HT-PEFC show that the phosphoric acid loss through evaporation is very small. At $T=160^{\circ} \mathrm{C}$ losses of $36 \cdot 10^{-8} \mathrm{~g} \mathrm{~cm}^{-2} \mathrm{~h}^{-1}$, 82 $10 \cdot 10^{-8} \mathrm{~g} \mathrm{~cm}^{-2} \mathrm{~h}^{-183}$ were observed. A slighthly smaller value of $5.4 \cdot 10^{-8} \mathrm{~g} \mathrm{~cm}^{-2} \mathrm{~h}^{-1}$ was reported for heat treated PBI membranes. ${ }^{79}$ The rate of evaporation increases exponentially with temperature, but even the increase of one order of magnitude would still have no significant effect on the total amount of phosphoric acid inside a HT-PEFC, which agrees well with a long term investigation. ${ }^{82}$ Another pathway for phosphoric loss seems to be redistribution through the GDL into the bipolar plates. ${ }^{84}$ Investigations at the end of life for HT-PEFC showed that $10 \%$ to $20 \%$ of the total amount of phosphoric acid could 
be found in bipolar plates made of graphite composite. ${ }^{85}$ This leads to corrosion of graphitic bipolar plates, as described for PAFCs. ${ }^{86}$ In the case of PAFC an active transport of phosphoric acid toward the anode is described. ${ }^{5,87}$

It should be noted that any change of the phosphoric acid electrolyte is strongly coupled with the water balance of the cell. The overall resistance of a HT-PEFC is higher under OCV conditions than under load and an increase in stochiometry also leads to a slight increase in overall resistance. ${ }^{88}$ If humidified gases are used the resistance of the electrolyte decreases ${ }^{89}$ due to a dillution effect. At the same time the cell performance decreases, presumably due to additional acid redistribution or leaching processes. ${ }^{89,90}$ In HT-PEFC degradation experiments at relatively high current density of $0.7 \mathrm{~A} \mathrm{~cm}^{-2}$ the loss of phosphoric acid was reported to have a significant impact. ${ }^{55}$ For lower current densities $\left(0.6 \mathrm{~A} \mathrm{~cm}^{-2}\right.$ to $\left.0.2 \mathrm{~A} \mathrm{~cm}^{-2}\right)$ it was shown that internal resistance does not change significantly, ${ }^{58,91,92}$ i. e. the loss of phosphoric acid is not significant.

\section{Degradation Models}

Degradation can be characterized at several levels. It is beyond the scope of this article to discuss these effects on an atomic scale. An overview of atomic modeling of platinum dissolution and meso-scale modeling of carbon corrosion can be found here. ${ }^{93}$ In many cases fuel cell degradation occurs through a combination of several effects. An uncompromisingly approach would consider all effects at once. This requires a coupling of different scales. Such an approach for catalyst degradation, carbon corrosion and membrane degradation was presented for PEFC $^{94}$ and HT-PEFC. ${ }^{95}$ It gives detailed information but requires many parameters of the respective fuel cell system. The opposite approach is to drastically reduce the level of detail or to focus on one specific degradation mode. Such models are favorable if only a restricted set of information is available or a more general answer is preferred. This class of models is discussed in the following. A common approach is to use a suitable model for the polarization curve as starting point which contains parameters with physical meaning. Based on a specific degradation mechanism suitable degradation functions can be defined. The number of functions depends on the mechanistic point of view. Therefore, degradation models are often used to test and support a certain hypothesis.

One example is the effect of catalyst degradation which can be described by assuming several reaction pathways. A model with 3 reaction pathways was demonstrated to describe the effects of platinum dissolution, platinum oxide film formation, chemical dissolution of platinum oxide. ${ }^{96}$ This model class has been later applied to particle size distribution of the catalyst and the crossover of hydrogen was included. ${ }^{97}$ The effect of carbon corrosion under local starvation (reverse current regime) was described as a single rate reaction with a Tafel-like approach. ${ }^{98}$ As a result cathode catalyst layer thinning is assumed. A refined model with 2 effective reaction steps was introduced ${ }^{99}$ which describes the resulting double layer capacitance. A further refined version with 7 separate reaction rates yielded carbon weight loss and surface oxide growth as a function of time, temperature, and potential. ${ }^{100}$ In order to additionally include effects like surface oxide groups and $\mathrm{OH}$ radicals a model with 16 separate reaction rates was proposed. ${ }^{101}$ The model shows that the formation of surface oxides on platinum and carbon support is a key feature in the degradation reaction. In order to resolve local carbon corrosion anode $^{102}$ and cathode ${ }^{103}$ two dimensional models have been developed which link corrosion to distribution of local current density. A one dimensional model along the channel was applied to model carbon corrosion in dead end mode $\mathrm{PEFC}^{104}$ with good qualitative agreement. Recently a model was presented that combines reaction rate models with empirical correlation to fuel cell performance loss. ${ }^{105}$ This model showed quantitative agreement for both performance loss and evolution of $\mathrm{CO}_{2}$ as a result of carbon corrosion.

Nafion type membranes do release flouride ions as a result of the degradation process. The release of these ions was modeled with a single first order reaction rate ${ }^{77}$ and showed good agreement with experimental results. Based on the idea that hydrogen peroxide may be produced at the surface of platinum nano crystals within the membrane models with five reaction steps, ${ }^{106}$ seven reaction steps ${ }^{107}$ and eleven reaction steps ${ }^{108}$ have been proposed. These models explicitely describe the balance between radical generation and radical quenching which could explain nonlinear trends of fluoride emission.

The effect of humidity cycling where mechanical stress is a source for membrane degradation was modeled for GORE-SELECT membranes in a three step algorithm. ${ }^{109}$ Based on an initial model for the behavior at different relative humidities the distribution of stress in the membrane is calculated. These values serve as input for the degradation model with in turn yields a prediction of membrane lifetime, which showed good agreement with experiments. The general effect that changes in hydration state may lead to disastrous movement of polymer chains was described earlier for PBI membranes ${ }^{110}$ where a loss of modulus was predicted.

Another model application is to explore different degradation mechanism in order to identify dominating processes. By applying an agglomerate type model for the polarization curve of a PEFC it could be shown that catalyst degradation does not only lead to loss of ECSA but also increases mass transport resistance. ${ }^{111}$ The model considers an effective film thickness of electrolyte around the catalysts. The analysis of a steady state aging test at $0.6 \mathrm{~A} \mathrm{~cm}^{-2}$ for HT-PEFC showed that the losses could be explained mainly by loss of ECSA. ${ }^{91}$ In case of a higher current density of $0.7 \mathrm{~A} \mathrm{~cm}^{-2}$ the loss of phosphoric acid was reported to have a significant impact. ${ }^{55}$ In a recent approach empirical degradation functions were applied which decrease linearly with time. This analysis yielded also for low current densities of $0.2 \mathrm{~A} \mathrm{~cm}^{-2}$ an impact of both catalyst degradation and loss of phosphoric acid presumably through re-distribution. ${ }^{112}$ It was found that the initial doping level is a critical parameter for HT-PEFC degradation. With a similar model the lifetime of a HT-PEFC as function of operation temperature was shown, ${ }^{113}$ although in this case the degradation parameters were yielded from a polynomal fitting function. A very recent approach combined experiments and CFD simulation in order to resolve degradation locally for a HT-PEFC under constant load conditions. ${ }^{114}$ The model is based on an empirical estimation method of 8 parameters ${ }^{115}$ and detected both catalyst degradation and presumably loss of electrolyte as the main driving forces. One major result of this work is that degradation does not occur homogeneously over the active cell area.

Analytic models in contrast are very powerful to derive general degradation pattern. In a one dimensional model the effect of degradation occuring at the interface of membrane and catalyst layer was explored. ${ }^{116}$ The results show that as long as half of the catalyst layer remains intact the impact on overall performance my be small. Another model describes a non-uniform degradation of catalyst layers along the channel, which would correspond to a common distribution of current density in a single channel. ${ }^{117}$ The general propagation of a degradation wave along the channel was described in an earlier work. ${ }^{118}$ This model reproduces three phases of cell degradation: of stable operation, slow decrease of cell performance over a certain time and fast performance decay at the end of lifetime.

\section{Experimental}

The accelerated stress test was performed with single cell test rigs. Four HT-PEFC Celtec P1000 MEAs were used (phosphoric acid/ PBI system) which were operated at $160^{\circ} \mathrm{C}$. The temperature was controlled by electric heaters inside end plates made of steel. The cells were not thermally insulated. A three-fold meander flow field (graphitic) was used with an active area of $16.65 \mathrm{~cm}^{2}$. The cells were run on pure hydrogen/ air with fixed stochiometric ratio of $2 / 2$ in co-flow configuration. All gases were not humidified. The maximum power point of new HT-PEFC Celtec P1000 MEAs with this flow configuration is $0.42 \mathrm{~W} \mathrm{~cm}$ at $1.1 \mathrm{~A} \mathrm{~cm}^{2}$. In previous experiments it was observed that degradation occurs if the cell is operated near the maximum power point. Therefore it was decided to further increase the 

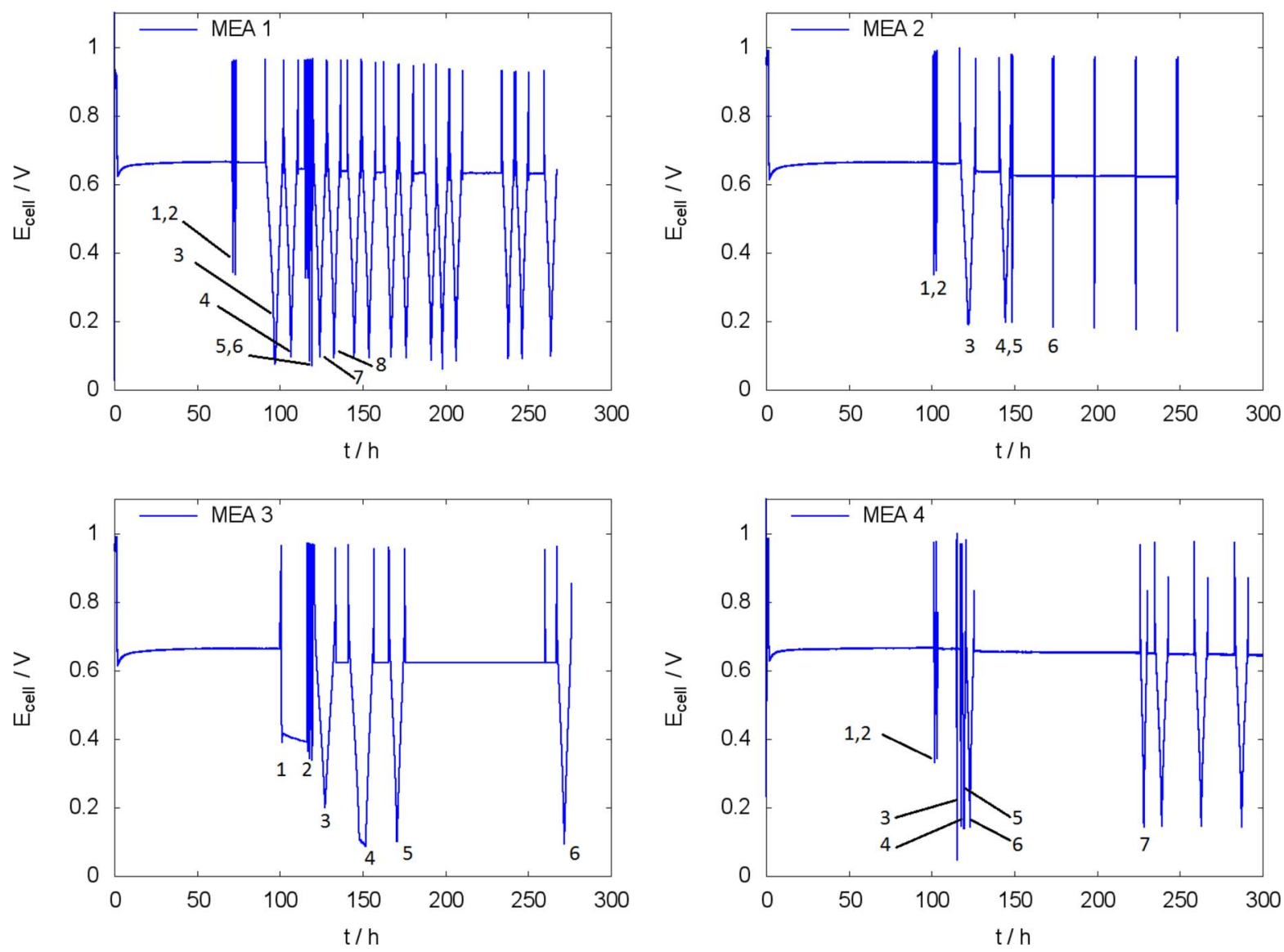

Figure 1. (Color online) Cell voltage versus time; The numbers mark the peaks for the polarization curves in Figure 3.

current density for the accelerated stress test. The cells were operated for approx. 300 hours. The base load was set at $0.2 \mathrm{~A} \mathrm{~cm}^{2}$. At arbitrary point in time polarization curves were recorded to mimic a load peak. For each of the four cells a different load profile was applied in order to test whether differences in frequency or number of excursions to low voltage/ high current have influence on the total degradation. The first two polarization curves were recorded right up to the maximum power point in order to compare the performance. This performance was identical for all four cells.

The load profiles are shown in Figure 1. The numbered peaks have been selected for further analysis. Figure 2 shows an enlarged section for MEA 1 and MEA 4 since the peaks are very dense in time. The corresponding current is shown in the plot of polarization curves in Figure 3. It can be observed that the polarization curves show severe hysteresis effects if the cell is operated above $1.1 \mathrm{~A} \mathrm{~cm}^{2}$. This degradation effect seems to be irreversible with one exception: the polarization curve number 4 for MEA 1 is slightly lower than the following peaks number 5 and 6 . In that special case the cell seemed to recover slightly. In all other cases degradation is clearly irreversible within the time of the experiments. It seemed that further degradation stopped or diminished once the polarization curves did not reach the current of $1.1 \mathrm{~A} \mathrm{~cm}^{2}$. (It should be mentioned that the lower limit for the cell voltage was set at $0.1 \mathrm{~V}$ at the test rig.) All subsequent polarization curves overlap almost completely. The polarization curves still contain some noise and jumps. Commonly, measured data from test rigs is pre-processed (without the meaning of
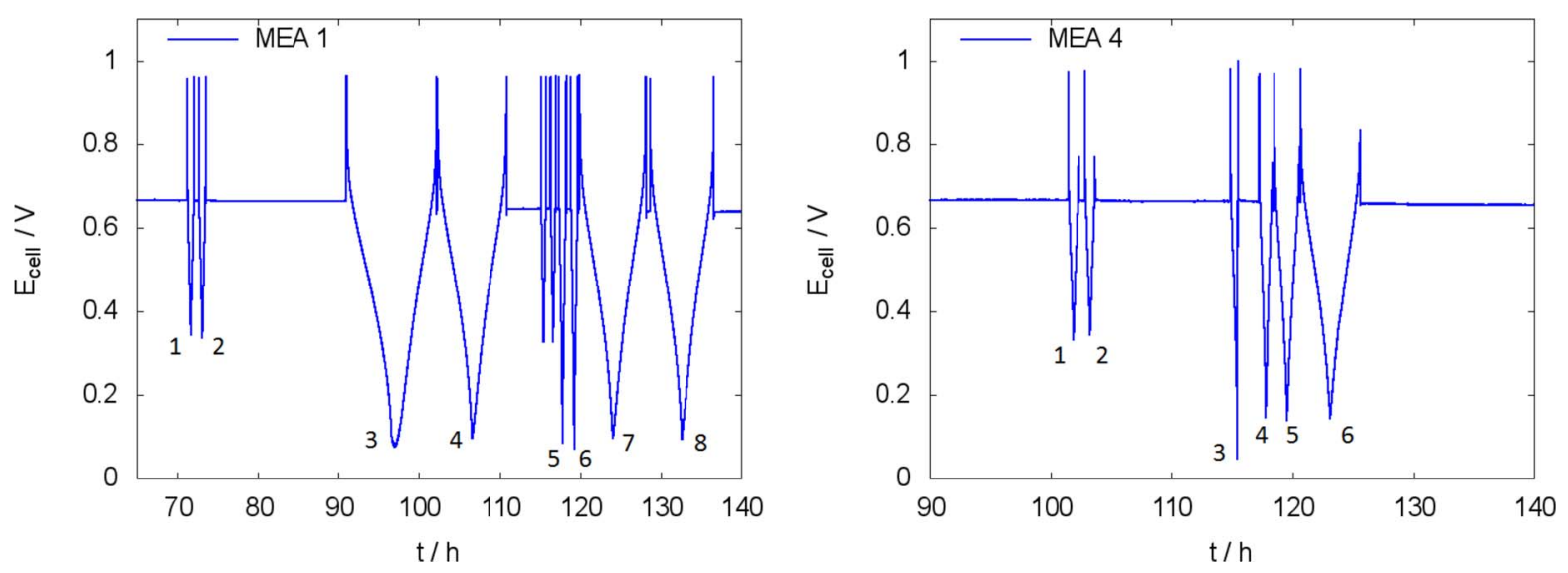

Figure 2. (Color online) Enlarged parts of cell voltage versus time for MEA 1 and MEA 4. 

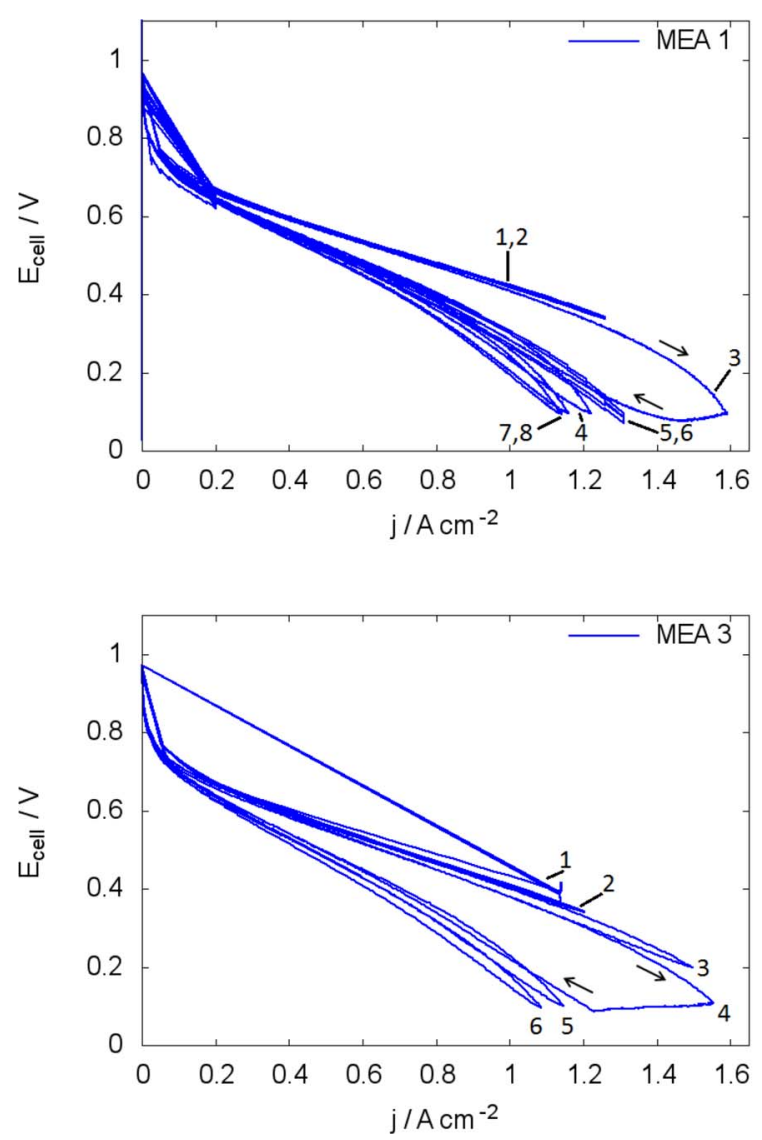

Figure 3. (Color online) Resulting polarization curves.

manipulation). This normal pre-processing step was avoided because the model analysis needs to be performed as much as possible on realistic data of the cells.

\section{Model Development}

Degradation reactions. - The modeling of degradation effects requires a model with suitable key variables that resemble respective properties of the fuel cell that are subject to degradation. These key variables change their value as a function of parameters like voltage, temperature and time which are considered to be the driving force for degradation. From the discussion of the literature a list of the most representative reactions can be derived which are related to catalyst dissolution, carbon corrosion and membrane degradation. These reactions occur each within their specific potential range which may vary with respect to the specific mix of electrode materials and operating conditions. Therefore, thermodynamic values are used within this modeling approach in order to define the limits of these degradation reactions. The standard voltage $E_{0}$ of a reaction can be calculated from the Gibbs energy $\Delta G$ according to Eq. 2, where $z$ is the number of exchanged electrons and $F$ is Faraday's constant.

$$
E_{0}=\frac{-\Delta G}{z F}
$$

There is one known problem with Eq. 2 in the context of degradation. The sign of $\Delta G$ changes with the direction of the reaction but $E_{0}$ does not. Otherwise the fuel cell reaction would take place at $1.23 \mathrm{~V}$ and water electrolysis as the reverse reaction at $-1.23 \mathrm{~V}-$ which is not true (see further discussion ${ }^{119}$ ). If one considers the electrochemical series, materials with a negative value of $E_{0}$ release electrons with respect to the standard hydrogen electrode. E. g. these materials are (thermodynamically) not stable in water or diluted acids. It can be assumed that degradation reactions for fuel cells should have a positive
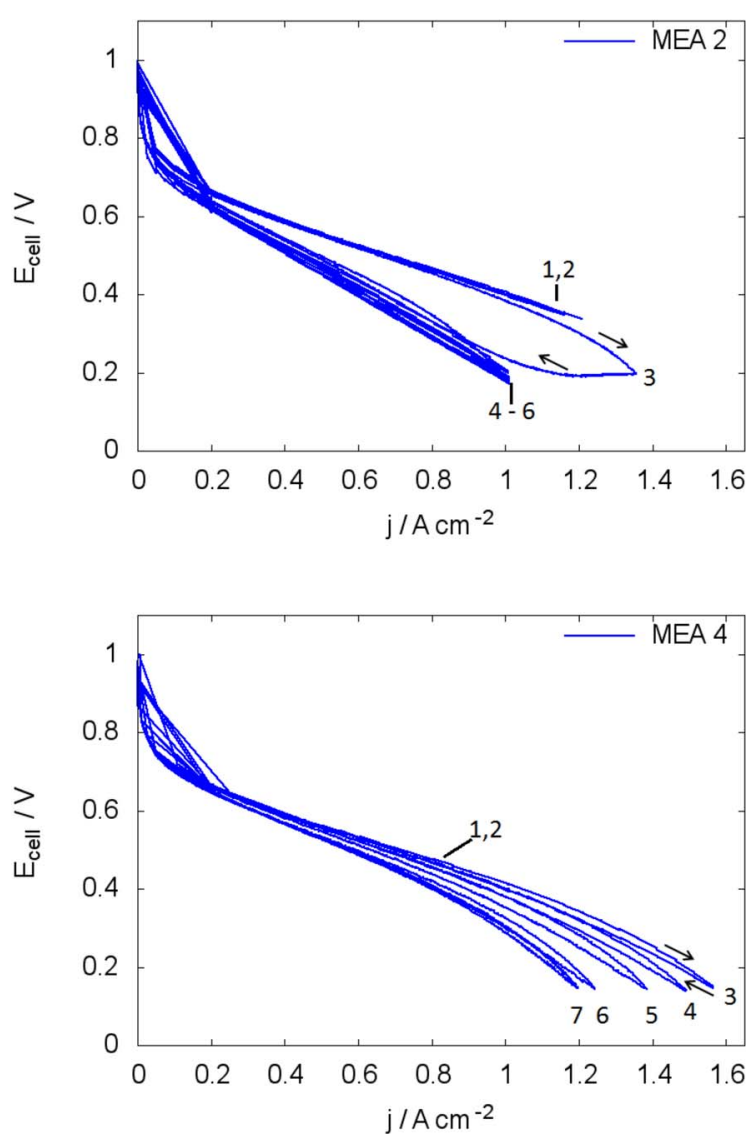

value of $E_{0}$, otherwise the sole presence of water would lead to serious damage. Therefore, Eq. 3 is used to calculate the values for $E_{0}$ based on thermodynamic data. ${ }^{120}$

$$
E_{0}=\left|\frac{-\Delta G}{z F}\right|
$$

The reactions in Table I appear in the order of decreasing standard voltage. Furthermore it is assumed that the catalyst surface is covered by a thin film of liquid water for PEFC ${ }^{121-123}$ or phosphoric acid/ water

\footnotetext{
Table I. Reactions and corresponding voltages based on thermodynamic data from ${ }^{120}$ for $25^{\circ} \mathrm{C}$ and $101.325 \mathrm{kPa} /$ values marked with ${ }^{*)}$ are calculated from $E_{0}$.
}

\begin{tabular}{lccc} 
Number & Reaction & $\Delta G / \mathrm{kJ} \mathrm{mol}^{-1} E_{0} / \mathrm{V}$ \\
\hline 1 & $\mathrm{CO}+0.5 \mathrm{O}_{2} \rightleftharpoons \mathrm{CO}_{2}$ & -257 & 1.33 \\
2 & $\mathrm{H}_{2}+0.5 \mathrm{O}_{2} \rightleftharpoons \mathrm{H}_{2} \mathrm{O}$ (liq.) & -237 & 1.23 \\
3 & $\mathrm{Pt} \rightleftharpoons \mathrm{Pt}^{2+}+2 \mathrm{e}^{-}$ & $\left.228^{*}\right)$ & 1.18 \\
4 & $\mathrm{C}+\mathrm{O}_{2} \rightleftharpoons \mathrm{CO}_{2}$ & -394 & 1.02 \\
5 & $\mathrm{Pt}+2 \mathrm{H}_{2} \mathrm{O}$ (liq.) $\rightleftharpoons \mathrm{PtO}_{2}+4 \mathrm{H}^{+}+4 \mathrm{e}^{-}$ & $\left.386^{*}\right)$ & 1.00 \\
6 & $\mathrm{C}+0.5 \mathrm{O}_{2} \rightleftharpoons \mathrm{CO}$ & -137 & 0.71 \\
7 & $\mathrm{H}_{2}+\mathrm{O}_{2} \rightleftharpoons \mathrm{H}_{2} \mathrm{O}_{2}$ (liq.) & -120 & 0.62 \\
8 & $0.5 \mathrm{H}_{2} \mathrm{O}_{2}$ (liq.) $+0.5 \mathrm{H}_{2} \rightleftharpoons \mathrm{H}_{2} \mathrm{O}$ (liq.) & -117 & 0.61 \\
9 & $\mathrm{C}+\mathrm{H}_{2} \mathrm{O}$ (liq.) $\rightleftharpoons \mathrm{CO}+\mathrm{H}_{2}$ & 100 & 0.52 \\
10 & $\mathrm{C}+2 \mathrm{H}_{2} \mathrm{O}$ (liq.) $\rightleftharpoons \mathrm{CO}_{2}+2 \mathrm{H}_{2}$ & 80 & 0.21 \\
11 & $\mathrm{CO}+\mathrm{H}_{2} \mathrm{O}$ (liq.) $\rightleftharpoons \mathrm{CO}_{2}+\mathrm{H}_{2}$ & -20 & 0.10 \\
$2 \mathrm{a}$ & $\mathrm{H}_{2}+0.5 \mathrm{O}_{2} \rightleftharpoons \mathrm{H}_{2} \mathrm{O}$ (gas) & -229 & 1.18 \\
$8 \mathrm{a}$ & $0.5 \mathrm{H}_{2} \mathrm{O}_{2}$ (gas) $+0.5 \mathrm{H}_{2} \rightleftharpoons \mathrm{H}_{2} \mathrm{O}$ (gas) & -123 & 0.64 \\
$7 \mathrm{a}$ & $\mathrm{H}_{2}+\mathrm{O}_{2} \rightleftharpoons \mathrm{H}_{2} \mathrm{O}_{2}($ gas) & -106 & 0.55 \\
$9 \mathrm{a}$ & $\mathrm{C}+\mathrm{H}_{2} \mathrm{O}$ (gas) $\rightleftharpoons \mathrm{CO}_{2}+\mathrm{H}_{2}$ & 92 & 0.48 \\
$10 \mathrm{a}$ & $\mathrm{C}+2 \mathrm{H}_{2} \mathrm{O}$ (gas) $\rightleftharpoons \mathrm{CO}_{2}+2 \mathrm{H}_{2}$ & 64 & 0.17 \\
$11 \mathrm{a}$ & $\mathrm{CO}+\mathrm{H}_{2} \mathrm{O}$ (gas) $\rightleftharpoons \mathrm{CO}_{2}+\mathrm{H}_{2}$ & -28 & 0.15
\end{tabular}


for HT-PEFC. ${ }^{124-126}$ Oxygen and hydrogen have to dissolve in this surface film and reach the electrode by diffusion. Consequently, water is produced in it's liquid state. At the bottom of Table I reaction data is also given for gas phase reactions to prove that the overall scheme does not differ if the afore mentioned assumption of the presence of a liquid film is questioned.

The working hypothesis of this paper is that a degradation reaction occurs if the cell voltage is above or equal to the value for $E_{0}$. (Actually, this behavior should be true for reactions with postive $\Delta G$ and opposite for negative $\Delta G$. In this respect the interpretation of Table I might not be fully consistent with theory ${ }^{119}$ but seems to be consistent with experiments.) It should further be noted that the data in Table $\mathrm{I}$ is given for standard conditions, i. e. for $25^{\circ} \mathrm{C}$ and $101.325 \mathrm{kPa}$. The values should be corrected for the influence of temperature and local concentrations. Besides that it must be considered that the electrodes are composite materials. Furthermore, the resulting voltage of a degradation process would be $E_{0}$ minus losses (similar to a fuel cell). These losses should be small since the currents associated with degradation are very small compared to the total current of the fuel cell. Therefore, the data for degradation reactions in Table I give a rough orientation and will be used to guide the general discussion.

In the following the data from Table I is discussed shortly within the framework of experimental data in order to check its plausibility. Table I contains two reactions for platinum dissolution at $1.18 \mathrm{~V}$ and $1.00 \mathrm{~V}$. Carbon corrosion via direct oxidation also yields two reactions at $1.02 \mathrm{~V}$ and $0.71 \mathrm{~V}$, respectively. The overall range from OCV to $0.7 \mathrm{~V}$ agrees very well with experimentally observed cathode catalyst degradation. It also agrees with the fact that the so called platinum band forms usually in the vicinity of the cathode, ${ }^{6}$ because dissolution occurs only at the cathode side. Commonly, the reactions of water with carbon at $0.52 \mathrm{~V}$ and $0.21 \mathrm{~V}$ are quoted as the general source for carbon corrosion. ${ }^{6-13}$ The cathode potential of a working fuel cell is ususally between $1.0 \mathrm{~V}$ and $0.5 \mathrm{~V}$. Therefore, these reactions should not occur at the cathode. At the anode these reactions would occur at high anodic half cell potential, i. e. under fuel starvation conditions. It must be mentioned that the actual reaction pathways for carbon corrosion are very complex ${ }^{39,40,127}$ and the data in Table I is likely to be oversimplified. Nevertheless it seems to provide a consistent framework for the overall processes.

The formation of hydrogen peroxide at the cathode as a side product of the fuel cell reaction occurs at $0.62 \mathrm{~V}$. It was observed experimentally at $0.7 \mathrm{~V} .^{68}$ The peroxide can be reduced with crossover hydrogen at almost the same potential of $0.61 \mathrm{~V}$. On the other hand hydrogen peroxide decomposes readily and releases radicals. The exact mechanism seems not to be fully understood at present. ${ }^{10}$ The radicals in turn may damage the membrane and decrease the hydrophobicity of the catalyst layers. ${ }^{6,10}$ Overall, this degradation mode seems to have little impact on short time scales but becomes significant in the long term because peroxide production occurs exactly in the normal operation range of a fuel cell.

It can be summarized that degradation of the cathode catalyst layer should occur in the range of OCV to $0.7 \mathrm{~V}$. Anode catalyst degradation should occur at anodic half cell potential above $0.2 \mathrm{~V}$, which corresponds to very low cell voltages $(<0.2 \mathrm{~V})$. The loss of phosphoric acid as degradation mode does not depend directly on voltage. Acid redistribution and removal strongly depend on local water balance and local temperatur within the cell. Therefore, electrolyte degradation should occur proportional to current. It could be possible that at very high current this process increases, e. g. due to restrictions in heat transfer which may lead to a drastic increase of local temperature. This could be translated to a critical voltage which should be below $0.5 \mathrm{~V}$ for a HT-PEFC operated at $160^{\circ} \mathrm{C}$ (depending on the shape of the polarization curve).

Modeling the polarization curve.- From the previous considerations two main degradation modes have been identified for the present experiment: catalyst degradation and electrolyte degradation. A very common modeling approach for the polarization curve is to calculate the cell voltage from the Nernst voltage minus kinetic losses. The chosen model is shown in Eq. 4, the Nernst equation is substituted by a constant value $E_{0}$. This can be justified by the fact that for a fixed stochiometry the average concentration should be constant. For convenience the open cell voltage was chosen for $E_{0}$.

$$
E_{\text {cell }}=E_{0}-R_{\Omega} j-\eta_{\text {act }}-\eta_{\text {trans }}
$$

The term $\eta_{\text {act }}$ describes kinetic losses of the catalyst layer and is calculated from the Tafel equation (Eq. 5). In order to minimize the number of parameters which have to be obtained from the polarization curve the contributions of anode and cathode are combined into one effective electrode. Thus, the values for $\alpha$ and $j_{0}$ contain both contributions from anode and cathode. Degradation of the catalyst layers, i. e. loss of ECSA, should lead to a decrease of the exchange current density $j_{0}$.

The electrolyte is considered under two different aspects. The term $R_{\Omega}$ contains mainly contributions from the protonic resistance of the MEA. A loss of phosphoric acid should lead to an increase of $R_{\Omega}$. Furthermore it is assumed that the electrode surface is covered by a thin film of phosphoric acid. The effective thickness of this film leads to a diffusion barrier, which in turn results in a limiting current density $j_{\text {lim }}$. The respective voltage loss $\eta_{\text {trans }}$ is described by Eq. 6 . Again, both anode and cathode are combined into one effective electrode. A change of the effective film thickness due to morphological changes of the catalyst layers or acid redistribution should lead to a change of $j_{\text {lim. }}$.

$$
\begin{gathered}
\eta_{\text {act }}=\frac{R T}{\alpha F} \ln \frac{j}{j_{0}} \\
\eta_{\text {trans }}=\frac{R T}{\alpha F} \ln \left(\frac{j_{\text {lim }}}{j_{\text {lim }}-j}\right)
\end{gathered}
$$

The final goal of this modeling approach is to mimic the polarization curves from Figure 3. For each of the four MEAs the data set contains approximately $150 \mathrm{~h}$ of operation with a resolution of $10 \mathrm{~s}$. In order to obtain a numerical solution the model must be able to iterate repeatedly over 54000 data points. Therefore, this rather simple approach was chosen. The initial values for all parameters were obtained from a reference measurement of the same cell/ MEA and are shown in Table II

(The effective parameter $\alpha$ also contains the number of electrons from the rate limiting step, as from theory the expression $\alpha \cdot n$ would result. The effective parameter $j_{0}$ contains also contributions from the average concentrations, because the Tafel equation (Eq. 5) usually includes the expression $j_{0} \cdot\left(c_{y} / c_{r e f}\right)$.)

Degradation model: voltage controlled.- The model described above contains three parameters which could be subject to degradation. The exchange current density $j_{0}$ is linked to the activity and ECSA of the catalyst. Catalyst degradation and carbon corrosion will lead to a decrease in $j_{0}$. The ohmic resistance $R_{\Omega}$ refers to proton conductivity of the membrane. Thus, membrane degradation will lead to a change in $R_{\Omega}$. A change in morphology of the catalyst layer or an increase of the effective thickness of the electrolyte film will increase the diffusion barrier for oxygen. Therefore, catalyst degradation and a change in phosphoric acid distribution will affect the value of $j_{\mathrm{lim}}$. For the following discussion these three parameters are refered to as

Table II. Model parameters.

$\begin{array}{lcl}\text { open cell voltage } & E_{0} & 0.96 \mathrm{~V} \\ \text { average (proton) resistance } & R_{\Omega} & 0.165 \Omega \mathrm{cm}^{2} \\ \text { effective symmetry factor } & \alpha & 0.75 \\ \text { exchange current density } & j_{0} & 1.2 \cdot 10^{-3} \mathrm{~A} \mathrm{~cm}^{-2} \\ \text { limiting current density } & j_{\lim } & 1.65 \mathrm{~A} \mathrm{~cm}^{-2} \\ \text { active cell area } & A_{\text {cell }} & 16.65 \mathrm{~cm}^{2} \\ \text { operating temperature } & T & 433 \mathrm{~K}\left(160^{\circ} \mathrm{C}\right)\end{array}$




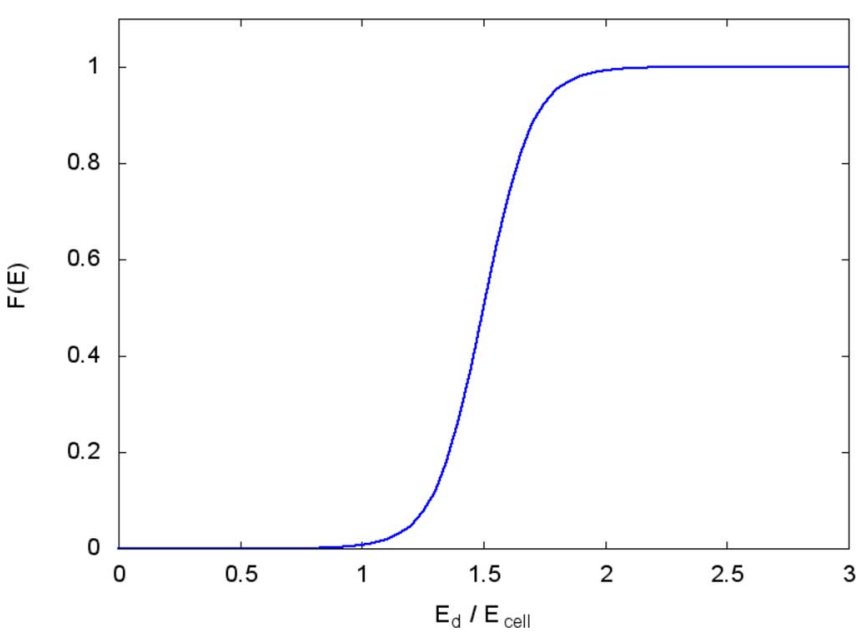

Figure 4. (Color online) Sigmoidal function for the onset of degradation at $E_{d}$ (with $a=10.0$ and $b=1.5$ ).

degradation parameter $X \in\left\{j_{0}, R_{\Omega}, j_{\text {lim }}\right\}$. The most simple approach is to assume that degradation occurs through a reaction with a single time constant (first order reaction). For each timestep, the value of $X$ would change by a magnitute $B$ (the rate constant) multiplied by the time interval $\Delta t$ (Eq. 7). The value at $X(t)_{t=0}$ corresponds to the initial value of the parameter in Table II.

$$
X_{t=n+1}=X_{t=n}+X_{t=n} \cdot B \cdot \Delta t
$$

Through a small re-arrangement (Eq. 8 and 9) it can be shown that this leads to an exponential behavior (Eq. 10).

$$
\begin{gathered}
X_{t=n+1}-X_{t=n}=X_{t=n} \cdot B \cdot \Delta t \\
\frac{d X}{d t} \approx \frac{X_{t=n+1}-X_{t=n}}{\Delta t}=X_{t=n} \cdot B \\
X(t)=X_{t=0} \cdot \exp (B \cdot t)
\end{gathered}
$$

The current from the recorded load profiles (Figure 1) is used as input for the model. Based on this dataset $j(t)$ the model calculates the resulting cell voltage according Eq. 4. The goal for the degradation model is to reproduce the polarization curves from Figure 3. From the considerations mentioned before it can be concluded that the onset for the degradation reaction should be related to a certain cell voltage. (A uniform voltage across the active cell area is assumed by the model which is consistent with experimental observation.) Therefore, Eq. 7 is extended by a sigmoidal function $F(E)$. The idea is to generate a 'voltage switch' which turns degradation on or off depending on the underlying mechanism in Table I. The sigmoidal function $F(E)$ is defined by Eq. 11 and shown in Figure 4.

$$
F(E)=\frac{1}{1+\exp \left(-a \cdot\left(\frac{E_{d}}{E_{\text {cell }}}-b\right)\right)}
$$

This equation contains three parameters which need to be explained. The voltage $E_{d}$ defines the onset of degradation and is normalized by the cell voltage. Parameter $b$ defines the value of the $\mathrm{x}$-axis where $F(E)=0.5$. For the model a fixed value of $b=1.5$ was chosen. Parameter $a$ defines the width or steepness of the function. For the model a fixed value of $a=10.0$ was chosen. For cell voltages larger than $E_{d}$ no degradation occurs. The onset of degradation starts at the point $E_{d} / E_{\text {cell }}=1.0$. With decreasing cell voltage the value of $F(E)$ increases until it reaches a maximum of $F(E)=1.0$ where cell voltage is half the value of $E_{d}\left(E_{d} / E_{\text {cell }}=2.0\right)$. The point at half of the maximum $(F(E)=0.5)$ is reached at $E_{d} / E_{\text {cell }}=1.5$ (parameter $b$ ). Thus, degradation 'intensity' is smeared over a certain voltage range. The underlying assumption is that degradation does not occur homogeneously in a fuel cell but is influenced by distribution of local concentrations, local temperature and local current. The onset of degradation occurs at the equilibrium voltage of the respective degradation reaction. With further decrease of cell voltage the potential difference increases which leads in turn to an increasing driving force for the reaction. This dynamic stops if the cell voltage reaches half the value of $E_{d}$. For the given application that should be at a sufficiently low cell voltage where any further increase will not make any difference. In preliminary tests it was found that the exact fitting result will of course depend on the choice of $a$ and $b$ but the general behavior remains very similar. (As an example the choice of $a=5$ will stretch the sigmoidal part from 0.5 to 2.5 whereas a value of $a=20$ will compress it to the range of 1.25 to 1.75 .)

Combining Eq. 11 with Eq. 12 and 13 leads to an expression for the degradation process which contains two 'fitting' parameters: the degradation rate $B$ and the onset value $E_{d}$.

$$
\begin{gathered}
X_{t=n+1}=X_{t=n}+X_{t=n} \cdot B \cdot \Delta t \cdot F(E) \\
X(t)=X_{t=0} \cdot \exp (B \cdot t \cdot F(E))
\end{gathered}
$$

In principle the degradation function (Eq. 12) can be applied to all three parameters $\left\{j_{0}, R_{\Omega}, j_{\text {lim }}\right\}$ simultaneously. This would result in a six parameter fit on one curve - the outcome would be questionable, because there will almost certainly be several possible solutions. In a first approach Eq. 12 is applied for each of the parameters $\left\{j_{0}, R_{\Omega}, j_{\text {lim }}\right\}$ separately. This would reveal whether there exists a single process with a major contribution to degradation. A close inspection of the polarization curves in Figure 3 reveals that the onset of degradation occurs at low cell voltage or high current respectively. Therefore, Eq. 11 is used for all parameters $\left\{j_{0}, R_{\Omega}, j_{\text {lim }}\right\}$, i. e. degradation occurs at values below $E_{d}$ and not above. For the fitting procedure the least square method was applied, i. e. the sum of least squares $S$ was calculated according to Eq. 14. The best fit represents a combination of $B$ and $E_{d}$ where the 'error' $S$ has it's minimal value. The total procedure is described below.

$$
S=\sum_{t}\left(E_{\text {cell,exp. }}(t)-E_{\text {cell,model }}\left(t, B, E_{d}\right)\right)^{2}
$$

1. For each MEA the load profile $j(t)$ was obtained from the data of the test rig.

2. One degradation parameter was selected from $\left\{j_{0}, R_{\Omega}, j_{\text {lim }}\right\}$.

3. For each $E_{d} \in[0.2 ; 0.5] \mathrm{V}$ and $B \in\left[1 \cdot 10^{-4} ; 1 \cdot 10^{-2}\right] \mathrm{s}^{-1}$ the steps are performed (brute force method):

(a) The cell voltage is calculated based on the load profile $j(t)$ from the test rig (Eq. 4 and including the degradation according Eq. 12).

(b) The sum of squares $S$ is calculated according Eq. 14 .

4. The combination of $B$ and $E_{d}$ which yields the least sum of squares is chosen as best fit.

This method ensures that the best fit represents the global minimum of $S$ if the width of the extremum is larger than the step size. Several step sizes were tested and finally the step size of 50 was chosen. (E. g. step size 100 yields the same solution.) The average time step of the experiment is $10 \mathrm{~s}$. Thus the result will emphasize a similar evolution in time rather than a perfect fit of the final polarization curve.

Reasonable fits could only obtained for parameter $R_{\Omega}$. Before discussing physical interpretations of the results the quality of the fit must be judged. Therefore, the resulting value of $S$ for all combinations $E_{d}$ and $B$ is shown in Figure 5 as an example. As can be seen the lowest values for $S$ follow an exponential decay. In order to estimate the uncertainty all results were collected which are within the range of $10 \%$ of the minimum value $S_{\min }$ for the sum of squares (i. e. $\left.\left[S_{\min } ; S_{\min }+0.1 S_{\min }\right]\right)$. Given the shape of the curve in Figure 5 a simple parameter variation would not be suitable.

The resulting polarization curves for the best fit are shown in Figure 6. It can be observed that the shapes of the curves are represented quite well but the extend of degradation is underestimated 


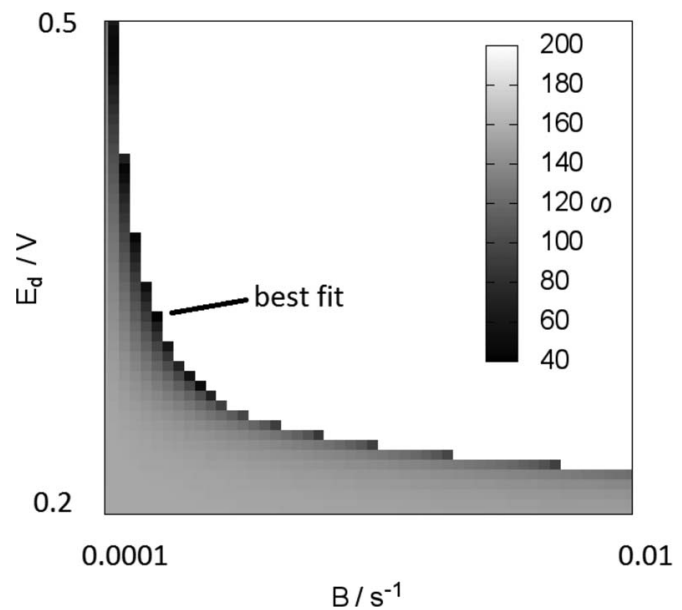

Figure 5. Resulting sum of squares $S$ for the fit of MEA 1; In the white region no fit is obtained because degradation is too high.

by the model. The corresponding values of $E_{d}$ and $B$ are listed in Table III. From the modeling perspective only parameter $E_{d}$ is of physical importance. The value of $B$ strongly depends on the width of the sigmoidal function (Eq. 11) which was set by intuition. The only hypothesis for the rate constant $B$ is that its value should be in the same order of magnitude for reasonable fits. This is more or less the case.

As a result of the fitting procedure the parameter $R_{\Omega}$ was identified to be the major subject of degradation. The onset of degradation occurs in the range from $E_{d}=0.48 \mathrm{~V}$ to $0.31 \mathrm{~V}$. A comparison to the degradation reactions in Table I yield two reactions for carbon
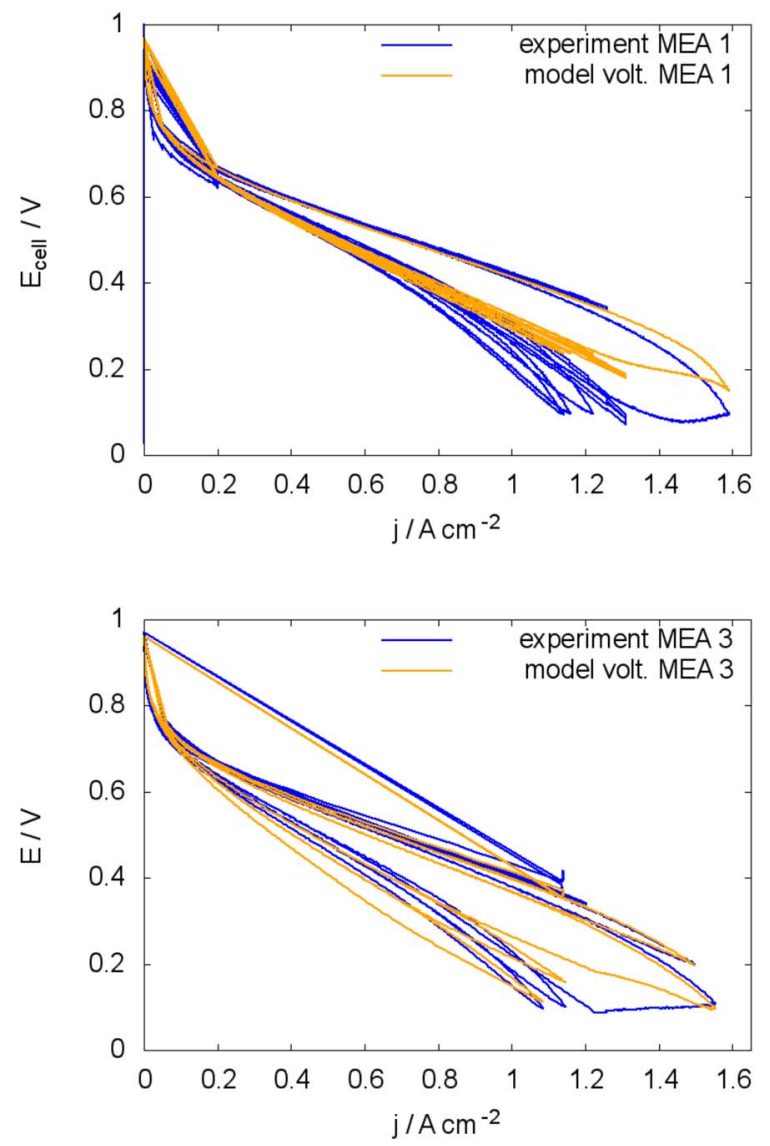

\begin{tabular}{|c|c|c|c|c|}
\hline & $E_{d}$ in $\mathrm{V}$ & $B$ in $\mathrm{s}^{-1}$ & $S$ & comment \\
\hline MEA 1 & $\begin{array}{l}0.320 \\
0.410\end{array}$ & $\begin{array}{c}10.99 \cdot 10^{-4} \\
4.96 \cdot 10^{-4}\end{array}$ & $\begin{array}{l}41.01 \\
44.30\end{array}$ & $\begin{array}{l}\text { lowest } E_{d} \text {, best fit } \\
\text { highest } E_{d}\end{array}$ \\
\hline MEA 2 & 0.476 & $8.92 \cdot 10^{-4}$ & 15.68 & best fit \\
\hline MEA 3 & $\begin{array}{l}0.422 \\
0.464 \\
0.482\end{array}$ & $\begin{array}{l}16.84 \cdot 10^{-4} \\
12.88 \cdot 10^{-4} \\
10.90 \cdot 10^{-4}\end{array}$ & $\begin{array}{l}2.86 \\
2.61 \\
2.79\end{array}$ & $\begin{array}{l}\text { lowest } E_{d} \\
\text { best fit } \\
\text { highest } E_{d}\end{array}$ \\
\hline MEA 4 & $\begin{array}{l}0.308 \\
0.326 \\
0.344\end{array}$ & $\begin{array}{l}92.08 \cdot 10^{-4} \\
58.42 \cdot 10^{-4} \\
38.62 \cdot 10^{-4}\end{array}$ & $\begin{array}{l}5.91 \\
5.65 \\
6.17\end{array}$ & $\begin{array}{l}\text { lowest } E_{d} \\
\text { best fit } \\
\text { highest } E_{d}\end{array}$ \\
\hline
\end{tabular}

corrosion in exactly the same range of $0.52 \mathrm{~V}-0.21 \mathrm{~V}$. Carbon corrosion could be caused by local starvation effects at low cell voltage or respective high current densities. This could in turn lead to a change in morphology of the catalyst layer, thus leading to an increase in ohmic resistance. On the other hand this degradation mechanism should also have a high impact on ECSA and limiting current density. During the experiment it was observed that while excursions to low voltage did cause degradation for the first several polarization curves it did have no effect on the subsequent curves.

Another possible interpretation is that operating the fuel cell below a certain voltage will affect membrane and/ or electrolyte because $R_{\Omega}$ is usually determined by the overall protonic conductivity. In this case cell voltage might not be a proper indicator for degradation. Furthermore it should be remembered that the above obtained fitting results do systematically underestimate the overall degradation effect.
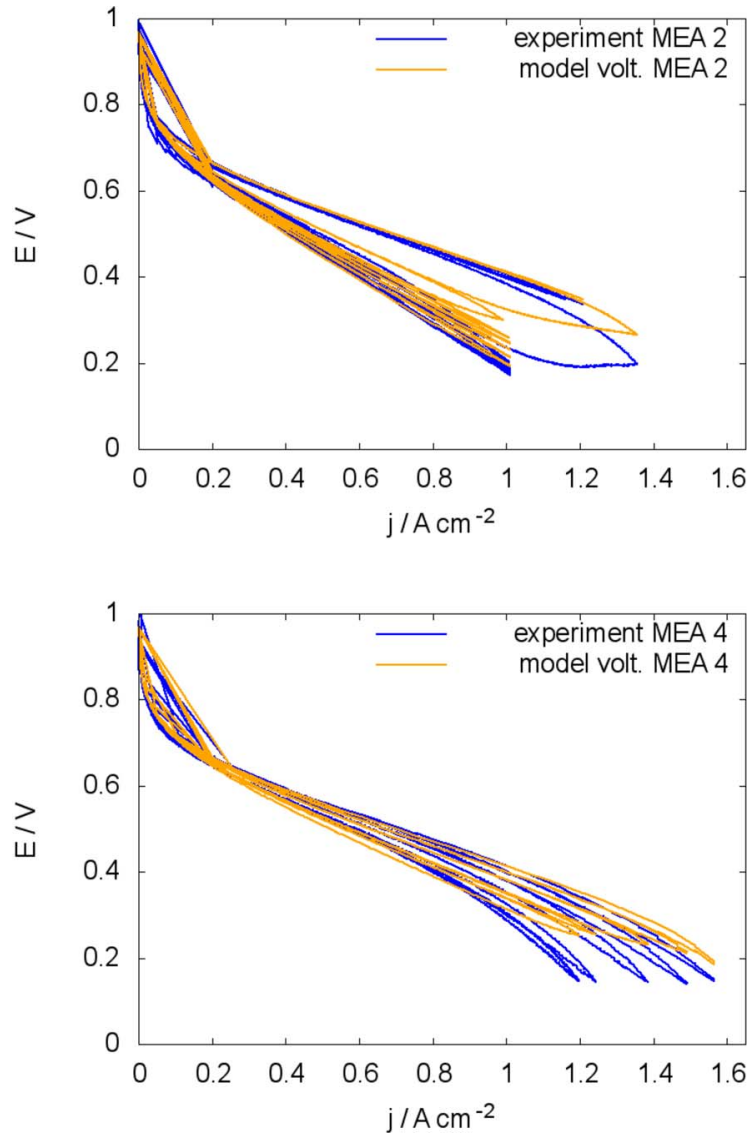

Figure 6. (Color online) Resulting polarization curves for voltage driven degradation of parameter $R_{\Omega}$. 

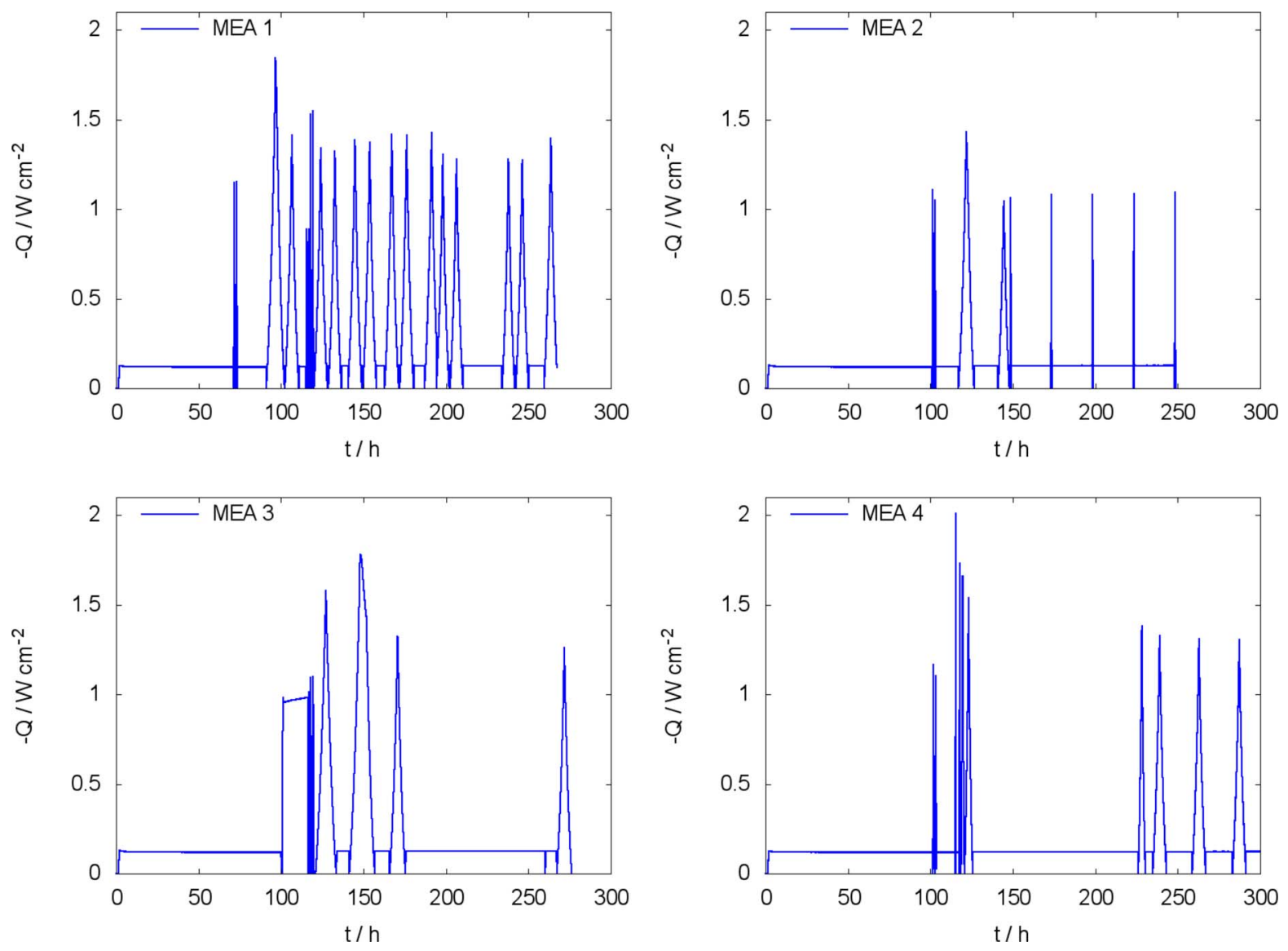

Figure 7. (Color online) Average heat flux versus time for the single cell experiments.

Therefore, the influence of heat as the driving force for degradation is explored in the next section.

Degradation model: heat controlled.- The analysis of the experimental the polarization curves from Figure 3 and the degradation modeling from the last section showed that degradation occurs at high current densities. Current itself should not be causing degradation as such. Yet current is linked to rate. The electro-chemical reaction in turn is connected to the release of electric energy and heat. A locally high heat generation could in turn lead to locally increased temperature at the catalyst layer, thus causing degradation. This would be enhanced by the fact that local current density is not distributed evenly at higher total current densities. ${ }^{128-130}$ Degradation can occur if the local temperature exceeds a critical value. The model itself does not resolve local effects, but the critical temperature can be roughly translated into a critical value of the overall heat flux. The heat flux of the cell $\dot{Q}$ can be calculated from the sum of reaction enthalpy and generated electricity. (Note that released heat has a negative sign.) Eq. 15 defines the overall heat flux for the single cell with $\Delta H=-242000 \mathrm{~J} \mathrm{~mol}^{-1}$ (water vapor, $25^{\circ} \mathrm{C}$ ) and $F=96484.55 \mathrm{~A} \mathrm{~s} \mathrm{~mol}^{-1}$.

$$
\dot{Q}=\frac{\Delta H \cdot j}{2 \cdot F}+E_{\mathrm{cell}} \cdot j
$$

As a first step the average heat flux for the four different load profiles is calculated from the experimental data and shown in Figure 7.

For degradation modeling the same approach is used like in the last section. As only difference a critical value of the average heat flux $\dot{Q}_{d}$ is assumed to trigger degradation. Therefore, the sigmoidal function $F(E)$ (Eq. 11) is substituted by $F(\dot{Q})$ (Eq. 16).

$$
F(\dot{Q})=\frac{1}{1+\exp \left(-10 \cdot\left(\frac{\dot{Q}_{\text {cell }}}{Q_{d}}-1.5\right)\right)}
$$

For small heat fluxes no degradation occurs. The onset of degradation starts at $\dot{Q}_{d}$ (i. e. $\dot{Q}_{\text {cell }} / \dot{Q}_{d}=1.0$ ). With further increase of $\dot{Q}_{\text {cell }}$ the value of $F(\dot{Q})$ increases until it reaches maximum when the heat flux is twice as much as $\dot{Q}_{d}$.

The fitting procedure was applied for each of the parameters $\left\{j_{0}, R_{\Omega}, j_{\text {lim }}\right\}$ separately. Again, very good agreement was found for the degradation of $R_{\Omega}$. The resulting polarization curves are shown in Figure 8. By comparing Figures 6 and 8 it can be recognized that the quality of the fit increased significantly. The same information can be obtained by comparing the values for the sum of squares (the 'error' of the fit). For MEAs 1, 2 and 3 the values of $S$ are much lower in Table IV compared to Table III. A general feature of the polarization curves in Figure 8 is that the quality of fit is good for the first curves and becomes worse for the following curves. This is understandable since the model is zero dimensional and does only correspond to average values of heat, current and voltage. Local distributions will have a significant effect on degradation and the resulting differences are added up for each time step. Furthermore, degradation seems to be reversible to a small extent - as discussed in section 'Experiment'. This is not considered in the model. Nevertheless, the model does provide an almost quantitative fit over the first $100 \mathrm{~h}$ at a resolution of $10 \mathrm{~s}$.

The resulting fitting parameters are shown in Table IV. The values for $\dot{Q}_{d}$ for the onset of degradation show a wide spread from $-0.61 \mathrm{~W} \mathrm{~cm}^{-2}$ to $-1.25 \mathrm{~W} \mathrm{~cm}^{-2}$. One possible explanation is the fact that the model calculates average values, whereas in reality the 

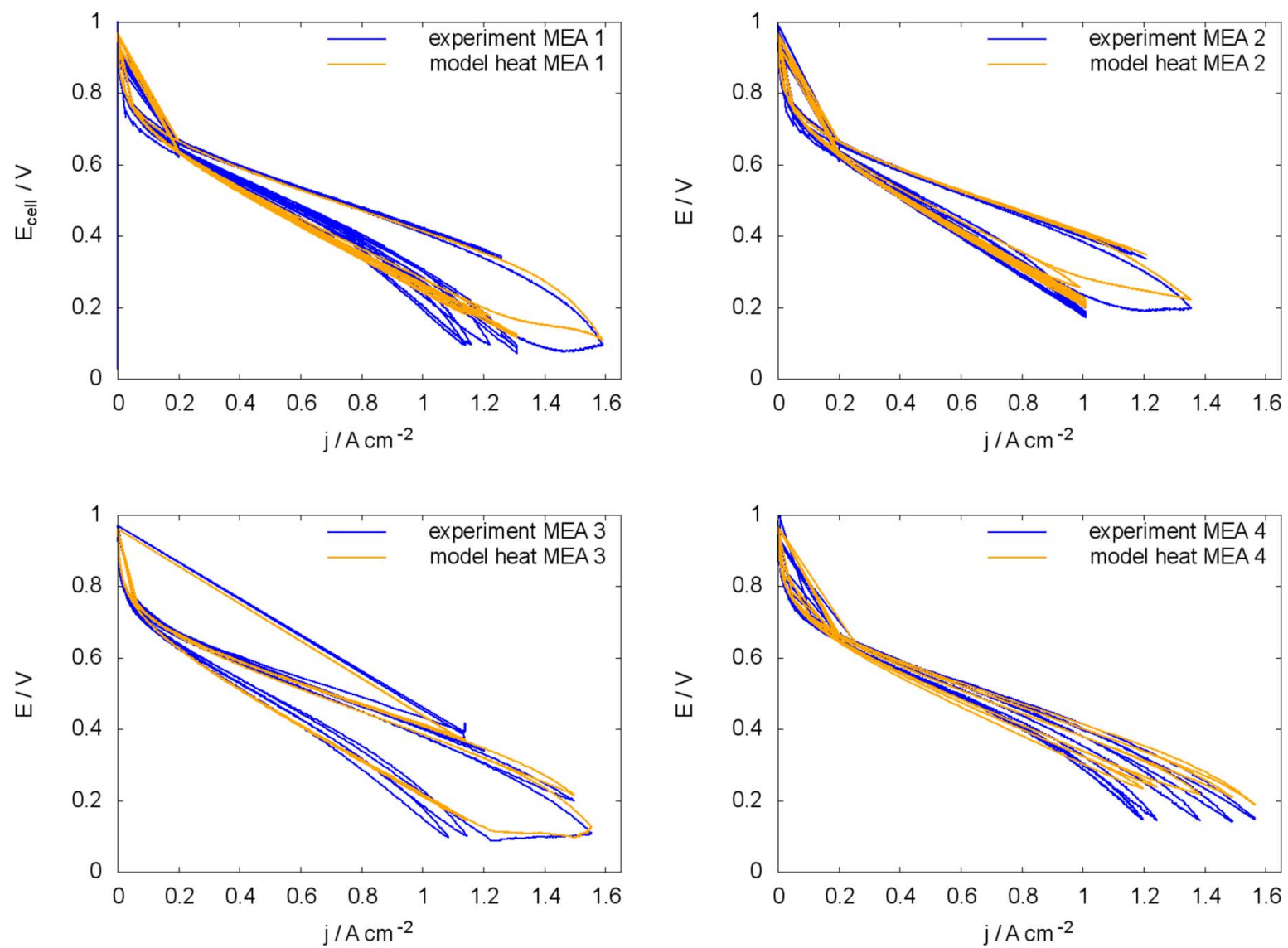

Figure 8. (Color online) Resulting polarization curves for heat driven degradation of parameter $R_{\Omega}$.

driving force for degradation are local values of heat and thus temperature. Another possible interpretation is the following. The model yields stable solutions over a wide range or $\dot{Q}_{d}$. This corresponds to the fact that small variations in heat conduction lead to a large spread in apparent onset values of $\dot{Q}_{d}$ since local temperature should be the real driving force for degradation. All cells have been assembled manually. This could lead to different levels of compression and thus to a difference in the resulting heat conductivity.

As a result it can be concluded that local overheating leads to an irreversible increase in resistance. One reason could be temperature induced damage to structural integrity of the polymer membrane. Another explanation could be the removal or redistribution of phosphoric

Table IV. Results of heat controlled degradation of $R_{\Omega}$, fitted in the range $\dot{Q}_{d} \in[-0.3 ;-2.0] \mathrm{W} \mathrm{cm}^{-2}$ and $B \in\left[1 \cdot 10^{-4} ; 1 \cdot 10^{-2}\right] \mathrm{s}^{-3}$; Results are obtained in the range of $10 \%$ of the least sum of squares $S$.

$\begin{array}{ccrrl} & \dot{Q}_{d} \text { in } \mathrm{W} \mathrm{cm} & & \\ \text { MEA 1 } & -0.84 & 6.94 \cdot 10^{-4} & 28.00 & \text { lowest } \dot{Q}_{d} \\ & -0.95 & 10.90 \cdot 10^{-4} & 27.25 & \text { best fit } \\ \text { MEA 2 } & -1.25 & 80.20 \cdot 10^{-4} & 27.84 & \text { highest } \dot{Q}_{d} \\ & -0.61 & 6.94 \cdot 10^{-4} & 6.49 & \text { lowest } \dot{Q}_{d} \text {, best fit } \\ \text { MEA 3 } & -0.91 & 54.46 \cdot 10^{-4} & 6.88 & \text { highest } \dot{Q}_{d} \\ & -0.88 & 24.76 \cdot 10^{-4} & 1.64 & \text { lowest } \dot{Q}_{d} \\ & -0.95 & 32.68 \cdot 10^{-4} & 1.60 & \text { best fit } \\ \text { MEA 4 } & -0.98 & 38.62 \cdot 10^{-4} & 1.64 & \text { highest } \dot{Q}_{d} \\ & -0.74 & 6.94 \cdot 10^{-4} & 4.99 & \text { lowest } \dot{Q}_{d} \\ & -0.84 & 12.88 \cdot 10^{-4} & 4.63 & \text { best fit } \\ & -1.08 & 88.12 \cdot 10^{-4} & 5.00 & \text { highest } \dot{Q}_{d}\end{array}$

acid from membrane and electrode. In theory the loss of phosphoric acid by evaporation should be very small. On the other hand high current is also coupled to production of large amounts of water which may dillute the phosphoric acid and increase its mobility, since the total volume of liquid electrolyte depends on the balance between water production and water removal. The change in total volume of electrolyte was also detected by in-situ synchrotron X-ray radiography for HT-PEFC. ${ }^{131}$ In a recent conference talk first results of X-ray tomographic microscopy were presented, ${ }^{132}$ which visualize movement of a liquid in the gas diffusion layer of a HT-PEFC operated under severe conditions at $160^{\circ} \mathrm{C}$. This experimental evidence together with the fact that a change of only $R_{\Omega}$ is required for very good agreement leads to a strong indication that the loss of phosphoric acid from the MEA is likely to be the major degradation mode at high currents. This degradation mechanism may be unique for the Celtec type MEAs, because due the production process the membrane contains an exceptional high amount of phosphoric acid. ${ }^{57,133}$

It should be mentioned that an apparent increase in ohmic resistance could also be caused agglomeration of catalyst particles. ${ }^{117}$ Such an interpretation would require more fitting parameters and is therefore considered to be less likely within this context. The presented hypothesis is also in agreement with other HT-PEFC degradation experiments. In case of a relatively high current density of $0.7 \mathrm{~A} \mathrm{~cm}^{-2}$ the loss of phosphoric acid was reported to have a significant impact. ${ }^{55}$ For lower current densities $\left(0.6 \mathrm{~A} \mathrm{~cm}^{-2}\right.$ to $\left.0.2 \mathrm{~A} \mathrm{~cm}^{-2}\right)$ it was shown that internal resistance does not change significantly, ${ }^{58,91,92}$ i. e. the loss of phosphoric acid is not significant. In another study it was also found that by increasing the operating temperature of a HT-PEFC up to $190^{\circ} \mathrm{C}$ the loss of phosphoric acid becomes a significant issue. ${ }^{95} \mathrm{In}$ an extreme case of a HT-PEFC operated up to $300^{\circ} \mathrm{C}$ severe catalyst degradation was identified as the major failure mode. ${ }^{134,135}$ At temperatures up to $200^{\circ} \mathrm{C}$ a sudden increase in mass transport limitation 
is reported ${ }^{134}$ for currents above $0.6 \mathrm{~A} \mathrm{~cm}^{-2}$ which agrees well with the above presented modeling result of redistribution of phosphoric acid.

\section{Conclusions}

An accelerated degradation test for high temperature polymer electrolyte fuel cells was performed where the fuel cell is constantly under load with frequent periods of very high current. Four different cells were operated each with a specific load profile. As a result severe performance degradation was observed in the region of high current densities. A simple polarization curve model was used to explore different possible degradation mechanisms. The modeling results allow for two different interpretations. Carbon corrosion reactions can explain the observed effects if cell voltage is assumed as the driving force for degradation. A better fit was obtained by using the overall heat flux as degradation criterion. In this case an increase in local temperature could lead to redistribution and loss of phosphoric acid from the MEA. The results are supported by the fact that the model yields consistent time dependend results for four different and non-periodic load cycles.

The loss of phosphoric acid could be explained by a combination of two effects. Firstly, local temperature at the catalyst sites increases at high current which decreases viscosity and enhances mobility of phosphoric acid. Secondly, the high water production rate at high currents may dillute the phosphoric acid. The total water concentration in the acid depends on the balance of electrochemical reaction rate and evaporation rate. The overall effect is a redistribution of phosphoric acid from the membrane electrode assembly into GDL and flow field. This is in general agreement with cell and stack experiments where phosphoric acid is frequently found at or in the graphitic bipolar plates at the end of life.

\section{Acknowledgment}

This work was partly funded by The Danish Council for Strategic Research in the frame of the $4 \mathrm{M}$ Centre. The authors thank A. A. Kulikovsky for helpful discussions.

\section{References}

1. F. N. Büchi, M. Inaba, and T. J. Schmidt, editors, Polymer Electrolyte Fuel Cell Durability, Springer, New York, Dordrecht, Heidelberg, London, (2009).

2. M. M. Mench, E. C. Kumbur, and T. N. Veziroglu, editors Polymer Electrolyte Fuel Cell Degradation, Elsevier, Amsterdam, Boston, Heidelberg, (2012).

3. S. Zhang, X. Yuan, H. Wang, W. Mérida, H. Zhu, J. Shen, S. Wu, and J. Zhang, Int. J. Hydrogen Energy, 34, 388 (2009).

4. M. Hicks and D. Pierport, In Polymer Electrolyte Fuel Cell Durability, F. N. Büchi, M. Inaba, and T. J. Schmidt, editors, 385. Springer, New York, Dordrecht, Heidelberg, London (2009).

5. H. R. Kunz, ECS Trans., 11, 1447 (2007).

6. R. Borup, J. Meyers, B. Pivovar, Y. S. Kim, R. Mukundan, N. Garland, D. Myers, M. Wilson, F. Garzon, D. Wood, P. Zelenay, K. More, K. Stroh, T. Zawodzinski, J. Boncella, J. E. McGrath, M. Inaba, K. Miyatake, M. Hori, K. Ota, Z. Ogumi, S. Miyata, A. Nishikata, Z. Siroma, Y. Uchimoto, K. Yasuda, K.-i. Kimijima, and N. Iwashita, Chem. Rev., 107, 3904 (2007)

7. X. Yu and S. Ye, J. Power Sources, 172, 145 (2007)

8. F. A. de Bruijn, V. A. T. Dam, and G. J. M. Janssen, Fuel Cell, 08, 3 (2008).

9. W. Schmittinger and A. Vahidi, J. Power Sources, 180, 1 (2008)

10. J. Wua, X. Z. Yuan, J. J. Martin, H. Wang, J. Zhang, J. Shen, S. Wu, and W. Merida, J. Power Sources, 184, 104 (2008)

11. N. Yousfi-Steiner, P. Moçotéguy, D. Candusso, and D. Hissel, J. Power Sources, 194, 130 (2009).

12. S. Zhang, X.-Z. Yuan, J. N. C. Hin, H. Wang, K. A. Friedrich, and M. Schulze, $J$. Power Sources, 194, 588 (2009).

13. Y. Yu, H. Li, H. Wang, X.-Z. Yuan, G. Wang, and M. Pan, J. Power Sources, 205 , 10 (2012).

14. C.-Y. Wang and U. Pasaogullari, editors, Modeling and Diagnostics of Polymer Electrolyte Fuel Cells, Springer, New York, Dordrecht, Heidelberg, London, (2010).

15. H. Wang, H. Li, and X.-Z. Yuan, editors, PEM Fuel Cell Failure Mode Analysis, CRC Press, Boca Raton, London, New York, (2012).

16. A. Z. Weber, R. L. Borup, R. M. Darling, P. K. Das, T. J. Dursch, W. Gu, D. Harvey, A. Kusoglu, S. Litster, M. M. Mench, R. Mukundan, J. P. Owejan, J. G. Pharoah, M. Secanell, and I. V. Zenyuk, J. Electrochem. Soc., 161, F1254 (2014).
17. S. Zhang, X.-Z. Yuan, and H. Wang, In PEM Fuel Cell Failure Mode Analysis, H. Wang, H. Li, and X.-Z. Yuan, editors, 3. CRC Press, Boca Raton, London, New York (2012).

18. S. S. Kocha, In Polymer Electrolyte Fuel Cell Degradation, M. M. Mench, E. C. Kumbur, and T. N. Veziroglu, editors, 89. Elsevier, Amsterdam, Boston, Heidelberg (2012).

19. V. Berejnov, Z. Martin, M. West, S. Kundu, D. Bessarabov, J. Stumper, D. Susac, and A. P. Hitchcock, Phys. Chem. Chem. Phys., 14, 4835 (2012).

20. M. Matsumoto, T. Miyazaki, and H. Imai, Phys. Chem. Chem. Phys., 115, 11163 (2011).

21. J. C. Meier, C. Galeano, I. Katsounaros, A. A. Topalov, A. Kostka, F. Schüth, and K. J. J. Mayrhofer, ACS Catal., 2, 832 (2012).

22. X. Wang, R. Kumar, and D. J. Myers, Electrochem. Solid-State Lett., 9, A225 (2006)

23. P. J. Ferreira, G. J. la O', Y. Shao-Horn, D. Morgan, R. Makharia, S. Kocha, and H. A. Gasteiger, J. Electrochem. Soc., 152, A2256 (2005).

24. K. Mitsuda, T. Murahashi, M. Matsumoto, and K. Usami, J. Appl. Electrochem., 23 19 (1993).

25. K. Mitsuda and T. Murahashi, J. Appl. Electrochem., 21, 524 (1991).

26. A. Honji, T. Mori, K. Tamura, and Y. Hishinuma, J. Electrochem. Soc., 135, 355 (1988).

27. E. Passalacqua, P. L. Antonucci, M. Vivaldi, A. Patti, V. Antonucci, N. Giordano, and K. Kinoshita, Electrochim. Acta, 37, 2725 (1992).

28. J. Aragane, H. Urushibata, and T. Murahashi, J. Appl. Electrochem., 26, 147 (1996).

29. H. Nara, S. Tominaka, T. Momma, and T. Osaka, J. Electrochem. Soc., 158, B1184 (2011)

30. L. M. Roen, C. H. Paik, and T. D. Jarvi, Electrochem. Solid-State Lett., 7, A19 (2004)

31. S. Maass, F. Finsterwalder, G. Frank, R. Hartmann, and C. Merten, J. Power Sources, 176, 444 (2008).

32. Y. Ishigami, I. Maeda, K. Takada, T. Hyakutake, T. Suga, J. Inukai, M. Uchida, Y. Nagumo, H. Nishide, and M. Watanabe, Electrochem. Solid-State Lett., 15, B51 (2012)

33. S. J. Ashton and M. Arenz, J. Power Sources, 217, 392 (2012).

34. H.-S. Oh, J.-H. Lee, and H. Kim, Int. J. Hydrogen Energy, 37, 10844 (2012).

35. Z. Zhao, L. Castanheira, L. Dubau, G. Berthomé, A. Crisci, and F. Maillard, J. Power Sources, 230, 236 (2013).

36. H. Schulenburg, B. Schwanitz, N. Linse, G. G. Scherer, A. Wokaun, J. Krbanjevic, R. Grothausmann, and I. Manke, J. Phys. Chem. C, 115, 14236 (2011).

37. P. Deevanhxay, T. Sasabe, K. Minami, S. Tsushima, and S. Hirai, Electrochim. Acta in press, doi: (2014).

38. J. Speder, A. Zana, I. Spanos, J. J. K. Kirkensgaard, K. Mortensen, M. Hanzlik, and M. Arenz, J. Power Sources, 261, 14 (2014).

39. K. Kinoshita, editor, Carbon: electrochemical and physicochemical properties, Wiley, New York, (1988).

40. M. Cai, M. S. Ruthkosky, B. Merzougui, S. Swathirajan, M. P. Balogh, and S. H. Oh, J. Power Sources, 160, 977 (2006).

41. M. Matsumoto, T. Manako, and H. Imai, ECS Trans., 16, 751 (2008).

42. D. A. Stevens and J. R. Dahn, Carbon, 43, 179 (2005).

43. Z. Y. Liu, J. L. Zhang, P. T. Yu, J. X. Zhang, R. Makharia, K. L. More, and E. A. Stach, J. Electrochem. Soc., 157, B906 (2010).

44. M. Hara, M. Lee, C.-H. Liu, B.-H. Chen, Y. Yamashita, M. Uchida, H. Uchida, and M. Watanabe, Electrochim. Acta, 70, 171 (2012).

45. K. H. Lim, H.-S. Oh, S.-E. Jang, Y.-J. Ko, H.-J. Kim, and H. Kim, J. Power Sources, 193, 575 (2009)

46. Y. Shao, R. Kou, J. Wang, V. V. Viswanathan, J. H. Kwak, J. Liu, Y. Wang, and Y. Lin, J. Power Sources, 185, 280 (2008).

47. P. Stonehart and D. Wheeler, In Modern aspects of electrochemistry, B. E. Conway, C. G. Vayenas, R. E. White, and M. E. Gamboa-Adelco, editors, 373. Springer/ Kluwer, New York, Boston, Dordrecht, London, Moscow (2005).

48. J. McBreen, H. Olender, S. Srinivasan, and K. V. Kordesch, J. Appl. Electrochem. 11, 787 (1981)

49. J. Aragane, T. Murahashi, and T. Odaka, J. Electrochem. Soc., 135, 844 (1988)

50. V. Alderucci, E. Passalacqua, N. Giordano, P. L. Antonucci, F. Parmigiani, and N. Ricci, J. Appl. Electrochem., 20, 235 (1990).

51. V. Alderucci, V. Recupero, L. Pino, R. Di Leonardo, D. L. Cocke, N. Giordano, and F. Parmigiani, J. Appl. Electrochem., 20, 811 (1990).

52. Z. Qi and S. Buelte, J. Power Sources, 161, 1126 (2006).

53. J. Hu, H. Zhang, Y. Zhai, and B. Yi, Int. J. Hydrogen Energy, 31, 1855 (2006).

54. Y. Zhai, H. Zhang, G. Liu, J. Hu, and B. Yi, J. Electrochem. Soc., 154, B72 (2007)

55. G. Liu, H. Zhang, J. Hu, Y. Zhai, D. Xu, and Z. Shao, J. Power Sources, 162, 547 (2006).

56. A. D. Modestov, M. R. Tarasevich, V. Y. Filimonov, and N. M. Zagudaeva, Elec trochim. Acta, 54, 7121 (2009).

57. T. J. Schmidt and J. Baurmeister, J. Power Sources, 176, 428 (2008).

58. Y. Oono, A. Sounai, and M. Hori, J. Power Sources, 210, 366 (2012).

59. A. P. Hitchcock, V. Berejnov, V. Lee, M. West, V. Colbow, M. Dutta, and S. Wessel, J. Power Sources, 266, 66 (2014).

60. A. Taniguchi, T. Akita, K. Yasuda, and Y. Miyazaki, J. Power Sources, 130, 42 (2004).

61. W. R. Baumgartner, P. Parz, S. D. Fraser, E. Wallnöfer, and V. Hacker, J. Power Sources, 182, 413 (2008)

62. S. D. Knights, K. M. Colbow, J. St-Pierre, and D. P. Wilkinson, J. Power Sources, 127, 127 (2004).

63. H. Tang, Z. Qi, M. Ramani, and J. F. Elter, J. Power Sources, 158, 1306 (2006).

64. C. A. Reiser, L. Bregoli, T. W. Patterson, J. S. Yi, J. D. Yang, M. L. Perry, and T. D. Jarvi, Electrochem. Solid-State Lett., 8, A273 (2005). 
65. N. Linse, G. G. Scherer, A. Wokaun, and L. Gubler, J. Power Sources, 219, 240 (2012).

66. J. Dillet, D. Spernjak, A. Lamibrac, G. Maranzana, R. Mukundan, J. Fairweather, S. Didierjean, R. L. Borup, and O. Lottin, J. Power Sources, 250, 68 (2014)

67. P. Trogadas and T. F. Fuller, In Polymer Electrolyte Fuel Cells - Science, Applications, and Challenges, A. A. Franco, editor, 401. CRC Press, Boca Raton, London, New York (2013).

68. K. Ono, Y. Yasuda, K. Sekizawa, N. Takeuchi, T. Yoshida, and M. Sudoh, Electrochim. Acta, 97, 58 (2013).

69. K. Ke, T. Hatanaka, and Y. Morimoto, Electrochim. Acta, 56, 2098 (2011).

70. S. Hommura, K. Kawahara, T. Shimohira, and Y. Teraoka, J. Electrochem. Soc., 155, A29 (2008)

71. Z. Chang, H. Pu, D. Wan, L. Liu, J. Yuan, and Z. Yang, Polym. Degrad. Stab., 94, 1206 (2009).

72. S. M. Dockheer, L. Gubler, P. L. Bounds, A. S. Domazou, G. G. Scherer A. Wokaun, and W. H. Koppenol, Phys. Chem. Chem. Phys., 12, 11609 (2010).

73. J. H. Liao, Q. F. Li, H. C. Rudbeck, J. O. Jensen, A. Chromik, N. J. Bjerrum, J. Kerres, and W. Xing, Fuel Cells, 11, 745 (2011).

74. B. Vogel, E. Aleksandrova, S. Mitov, M. Krafft, A. Dreizler, J. Kerres, M. Hein, and E. Roduner, J. Electrochem. Soc., 155, B570 (2008).

75. M. Kitazawa, A. Y. Nosaka, and Y. Nosaka, J. Appl. Electrochem., 38, 491 (2008).

76. M. Danilczuk, F. D. Coms, and S. Schlick, J. Phys. Chem. B, 113, 8031 (2009).

77. S. Kundu, K. Karan, M. Fowler, L. C. Simona, B. Peppley, and E. Halliop, J. Power Sources, 179, 693 (2008)

78. M. Marrony, R. Barrera, S. Quenet, S. Ginocchio, L. Montelatici, and A. Aslanides, J. Power Sources, 182, 469 (2008)

79. T. Ossiander, M. Perchthaler, C. Heinzl, and C. Scheu, J. Power Sources, 267, 323 (2014).

80. Q. F. Li, H. C. Rudbeck, A. Chromik, J. O. Jensen, C. Pana, T. Steenberg, M. Calverley, N. J. Bjerrum, and J. Kerres, J. Membr. Sci., 347, 260 (2010).

81. S. Yu, L. Xiao, and B. C. Benicewicz, Fuel Cells, 08, 165 (2008).

82. D. C. Seel, B. C. Benicewicz, L. Xiao, and T. J. Schmidt, In Handbook of Fuel Cells - Fundamentals, Technology and Applications, W. Vielstich, H. Yokokawa, and H. A. Gasteiger, editors, volume 5: Advances in Electrocatalysis, Materials, Diagnostics and Durability, 300, John Wiley \& Sons, New York (2009).

83. C. Wannek, B. Kohnen, H.-F. Oetjen, H. Lippert, and J. Mergel, Fuel Cells, 08, 87 (2008).

84. S. Matar, A. Higier, and H. Liu, J. Power Sources, 195, 181 (2010)

85. C. Hartnig and T. J. Schmidt, Electrochim. Acta, 56, 4237 (2011).

86. L. G. Christner, H. P. Dhar, M. Farooque, and A. K. Kush, Corrosion, 43, 571 (1987).

87. T. Murahashi, In Encyclopedia of Electrochemical Power Sources, C. K. Dyer, P. T. Moseley, Z. Ogumi, D. A. J. Rand, B. Scrosati, and J. Garche, editors, 564 Elsevier, Amsterdam (2009).

88. K. Wippermann, C. Wannek, H.-F. Oetjen, J. Mergel, and W. Lehnert, J. Power Sources, 195, 2806 (2010).

89. S. Galbiati, A. Baricci, A. Casalegno, and R. Marchesi, Int. J. Hydrogen Energy, 37, 2462 (2012).

90. M. Boaventura and A. Mendes, Int. J. Hydrogen Energy, 35, 11649 (2010).

91. J. Hu, H. Zhang, Y. Zhai, G. Liu, and B. Yi, Electrochim. Acta, 52, 394 (2006)

92. S. Galbiati, A. Baricci, A. Casalegno, and R. Marchesi, Int. J. Hydrogen Energy, 38, 6469 (2013)

93. K. Malek and T. Mashio, In Polymer Electrolyte Fuel Cells - Science, Applications, and Challenges, A. A. Franco, editor, 511. CRC Press, Boca Raton, London, New York (2013).

94. A. A. Franco, In Polymer Electrolyte Fuel Cells - Science, Applications, and Challenges, A. A. Franco, editor, 449, CRC Press, Boca Raton, London, New York (2013).

95. A. Suzuki, Y. Oono, M. C. Williams, R. Miura, K. Inaba, N. Hatakeyama, H. Takaba, M. Hori, and A. Miyamoto, Int. J. Hydrogen Energy, 37, 18272 (2012).

96. R. M. Darling and J. P. Meyers, J. Electrochem. Soc., 150, A1523 (2003).
97. E. F. Holby and D. Morgan, J. Electrochem. Soc., 159, B578 (2012).

98. J. P. Meyers and R. M. Darling, J. Electrochem. Soc., 153, A1432 (2006).

99. A. P. Young, V. Colbow, D. Harvey, E. Rogers, and S. Wessel, J. Electrochem. Soc., 160, F381 (2013)

100. K. G. Gallagher and T. F. Fuller, Phys. Chem. Chem. Phys., 11, 11557 (2009).

101. A. Pandy, Z. Yang, M. Gummalla, V. V. Atrazhev, N. Y. Kuzminyh, V. I. Sultanov, and S. Burlatsky, J. Electrochem. Soc., 160, F972 (2013).

102. N. Takeuchi and T. F. Fuller, J. Electrochem. Soc., 155, B770 (2008).

103. J. H. Ohs, U. Sauter, S. Maass, and D. Stolten, J. Power Sources, 196, 255 (2011).

104. J. Chen, J. B. Siegel, T. Matsuura, and A. G. Stefanopoulou, J. Electrochem. Soc., 158, B1164 (2011).

105. S. R. Dhanushkodi, S. Kundu, M. W. Fowler, and M. D. Pritzker, J. Power Sources, 267, 171 (2014).

106. K. H. Wong and E. Kjeang, J. Electrochem. Soc., 161, F823 (2014).

107. M. Gummalla, V. V. Atrazhev, D. Condit, N. Cipollini, T. Madden, N. Y. Kuzminyh, D. Weiss, and S. F. Burlatsky, J. Electrochem. Soc., 157, B1542 (2010).

108. M. Ghelichi, P.-É. A. Melchy, and M. H. Eikerling, J. Phys. Chem. B, in press, DOI: (2014).

109. S. F. Burlatsky, M. Gummalla, J. O'Neill, V. V. Atrazhev, A. N. Varyukhin, D. V. Dmitriev, and N. S. Erikhman, J. Power Sources, 215, 135 (2012).

110. N. Iwamoto, Polymer Engineering and Science, 34, 1070 (1994).

111. S. Jomori, N. Nonoyama, and T. Yoshida, J. Power Sources, 215, 18 (2012).

112. M. Kim, T. Kang, J. Kim, and Y.-J. Sohn, Solid State Ionics, 262, 319 (2014)

113. J. Kim, M. Kim, T. Kang, Y.-J. Sohn, T. Song, and K. H. Choi, Energy, 66, 41 (2014).

114. D. Úbeda, P. Cañizares, M. A. Rodrigo, F. J. Pinar, and J. Lobato, Int. J. Hydrogen Energy, in press, (2014).

115. D. Úbeda, F. J. Pinar, P. Cañizares, M. A. Rodrigo, and J. Lobato, Int. J. Hydrogen Energy, 37, 11308 (2012).

116. A. A. Kulikovsky, Electrochem. Commun., 12, 1780 (2010).

117. A. A. Kulikovsky, Electrochim. Acta, 123, 542 (2014).

118. A. A. Kulikovsky, Electrochem. Commun., 6, 75 (2004).

119. A. J. Bard and L. R. Faulkner, ELECTROCHEMICAL METHODS - Fundamentals and Applications, Wiley, New York, Weinheim, Toronto, 2nd edition, (1988).

120. D. R. Lide, editor CRC Handbook of Chemistry and Physics, CRC Press, Boca Raton, Boston, London, New York, 79 edition, (1998).

121. M. H. Eikerling, K. Malek, and Q. Wang, In PEM Fuel Cell Electrocatalysts and Catalyst Layers, J. Zhang, editor, 381. Springer, London (2008).

122. D. Harvey, J. G. Pharoah, and K. Karan, J. Power Sources, 179, 209 (2008).

123. E. Sadeghi, A. Putz, and M. Eikerling, J. Electrochem. Soc., 160, F1159 (2013).

124. Y. Oono, A. Sounai, and M. Hori, J. Power Sources, 189, 943 (2009).

125. T. Sousa, M. Mamlouk, and K. Scott, Chemical Engineering Science, 65, 2513 (2010)

126. A. Bergmann, D. Gerteisen, and T. Kurz, Fuel Cells, 10, 278 (2010).

127. K. H. Kangasniemi, D. A. Condit, and T. D. Jarvi, J. Electrochem. Soc., 151, E125 (2004).

128. D. Úbeda, F. J. Pinar, D. C. Orozco, P. Cañizares, M. A. Rodrigo, and J. Lobato, J. Appl. Electrochem., 42, 711 (2012).

129. L. Lüke, H. Janßen, M. Kvesić, W. Lehnert, and D. Stolten, Int. J. Hydrogen Energy, 37, 9171 (2012).

130. C. Siegel, I. Buder, and A. Heinzel, Electrochim. Acta, 112, 342 (2013).

131. W. Maier, T. Arlt, C. Wannek, I. Manke, H. Riesemeier, P. Krüger, J. Scholta, W. Lehnert, J. Banhart, and D. Stolten, Electrochem. Commun., 12, 1436 (2010).

132. S. H. Eberhardt, F. N. Büchi, and T. J. Schmidt, In 11th symposium on fuel cell and battery modeling and experimental validation (Winterthur, Switzerland, March 17-19, 2014)

133. T. J. Schmidt, In Polymer Electrolyte Fuel Cell Durability, F. N. Büchi, M. Inaba, and T. J. Schmidt, editors, 199. Springer, New York, Dordrecht, Heidelberg, London (2009).

134. Y. Tang, J. Zhang, C. Song, and J. Zhang, Electrochem. Solid-State Lett., 10, B142 (2007).

135. J. Zhang, C. Song, and J. Zhang, J. Fuel Cell Sci. Technol., 8, 051006-1 (2011). 